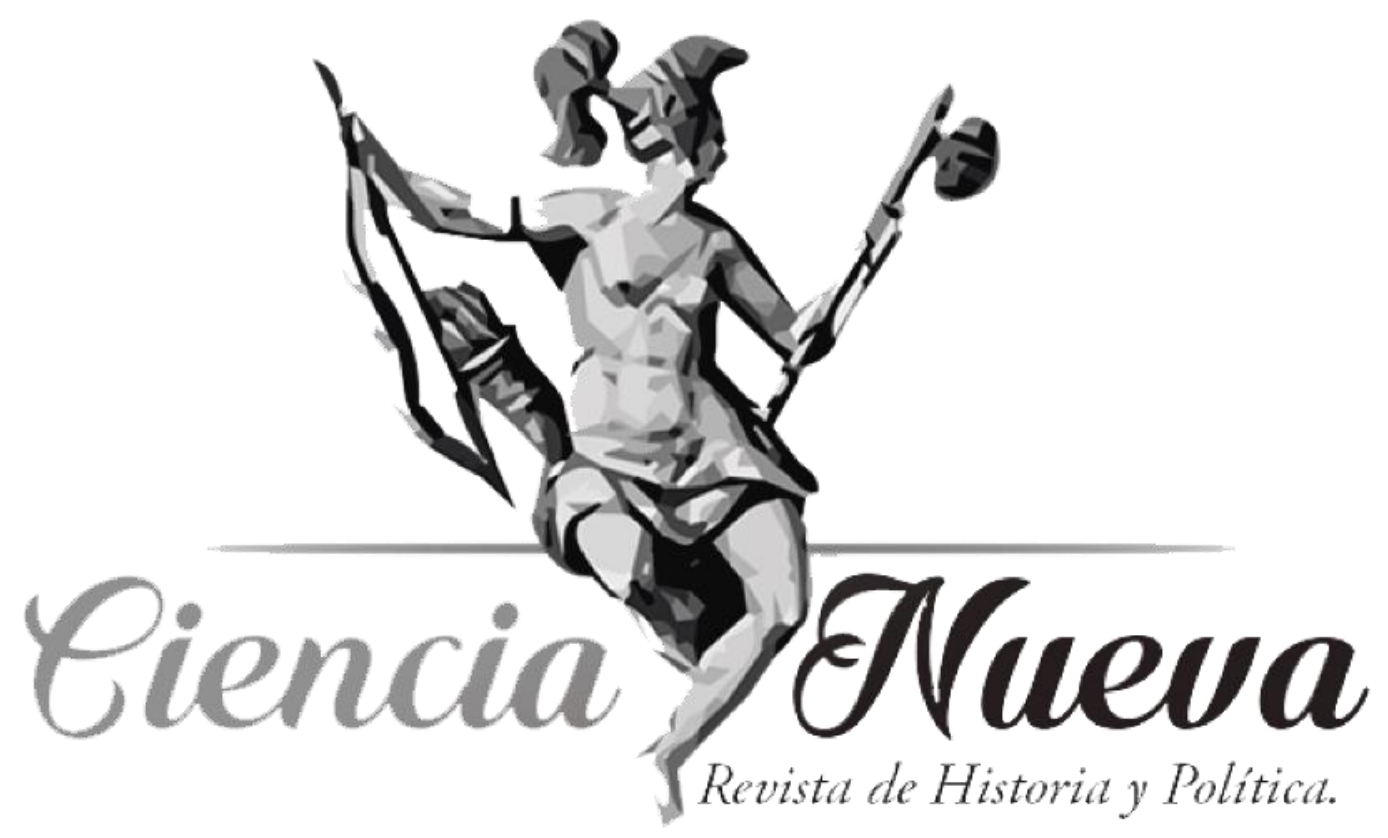

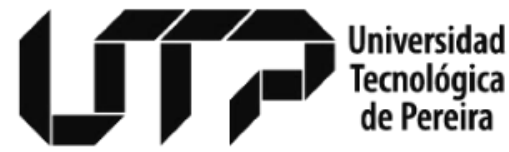

Maestría en Historia

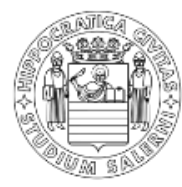

UNIVERSITÀ DEGLI STUDI DI SALERNO

ANALES Y MEMORIAS DEL CENTRO-OCCIDENTE COLOMBIANO

NOTAS E IMÁGENES TOMADAS EN EL MUSEO DEL ORO QUIMBAYA DEL BANCO DE LA REPÚBLICA, ARMENIA, COMPLEMENTADAS Y ORDENADAS

DE ACUERDO CON EL GUIÓN DE LA PÁGINA DE INTERNET DEL MUSEO

NOTES AND PICTURES TAKEN AT THE MUSEO DEL ORO QUIMBAYA OF THE BANK OF THE REPUBLIC, ARMENIA, COMPLEMENTED AND ORDERED BASED ON THE SCRIPT OF THE MUSEUM'S WEBSITE Luis Javier Caicedo pp. 215-261

Vol. 2 Núm. 1, Enero-Junio de 2018 Pereira, Colombia 


\section{NOTAS E IMÁGENES TOMADAS EN EL MUSEO DEL ORO QUIMBAYA DEL BANCO DE LA REPÚBLICA, ARMENIA, COMPLEMENTADAS Y ORDENADAS DE ACUERDO CON EL GUIÓN DE LA PÁGINA DE INTERNET DEL MUSEO* NOTES AND PICTURES TAKEN AT THE MUSEO DEL ORO QUIMBAYA OF THE BANK OF THE REPUBLIC, ARMENIA, COMPLEMENTED AND ORDERED BASED ON THE SCRIPT OF THE MUSEUM'S WEBSITE}

Jorge Hernán Velásquez ${ }^{* *}$ jorvelfortesa@gmail.com

ORCID: https://orcid.org/0000-0002-1843-6844

\begin{tabular}{rll}
\hline Recibido: & 20 de noviembre de 2017 \\
Revisado: & 28 de noviembre de 2017 \\
Aceptado: & 14 de diciembre de 2017 \\
Publicado: & 12 de marzo de 2018 \\
\hline
\end{tabular}

\section{Nota introductoria}

La información de este artículo corresponde al acercamiento a la extraordinaria información con la que contaba a mano en el Museo de Oro Quimbaya del Banco de la República de Armenia. Me pareció de suma importancia compartirla con todos los que pudiera hacerlo, de acuerdo a una compilación que tendría ya casi lista, tomé 250 fotografías, incluyendo las de los textos que acompañaban cada vitrina, los cuales hacen parte del artículo. Al efectuar la compilación encontré interesante complementarla con la página web del Banco de la República ${ }^{1}$, que es de público conocimiento, cuyo guion tenía información útil para los propósitos del documento que estaba elaborando.

\section{Milenios de historia en el Cauca Medio}

Los quimbayas eran uno de los grupos que habitaban el Cauca medio a la llegada de los conquistadores españoles. Por tradición todos los objetos arqueológicos encontrados en la región han sido denominados con el nombre Quimbaya y se ha identificado a los quimbayas como sus artífices, a pesar de que muchos de ellos fueron producidos por otra gente y en distintas épocas.

La región del Cauca medio, en los actuales departamentos de Quindío, Risaralda y Caldas, fue habitada a lo largo de milenios por sociedades con diferentes formas de vida y cultura.

\footnotetext{
* El presente artículo respeta las directrices y normas dispuestas en la Declaración de Ética de Publicación de Ciencia Nueva, Revista de Historia y Política. Esta declaración puede consultarse en la página web de la revista: revistas.utp.edu.co/index.php/historia.

** Ingeniero industrial de la Universidad de América, Bogotá. Asistente a los cursos de posgrado Trabajo por Proyectos de la Maestría en Administración de la Universidad Javeriana, y de Economía para no economistas de la Maestría en Economía de la Universidad Externado de Colombia.

1 Banrepcultural. Red cultural de la República en Colombia, acceso el 5 de marzo de 2018, www.banrepcultural.org/armenia/museo-del-oro-quimbaya-1
} 
Grupos de cazadores y recolectores la poblaron hace unos 10.000 años con modos de vida que mantuvieron por varios milenios. Hacia el 500 a.C. sus habitantes practicaban la agricultura y cerca del 100 d.C. trabajaban el oro; alrededor del año 800 estas sociedades sufrieron cambios profundos. La Conquista española en el siglo XVI produjo una disminución considerable de la población y grandes transformaciones sociales y culturales. El Museo del Oro Quimbaya en la ciudad de Armenia cuenta esta larga historia de un pasado que está presente en nuestros hombres y mujeres, costumbres, lenguaje, conocimientos y valores. Es una historia en permanente cambio y elaboración.

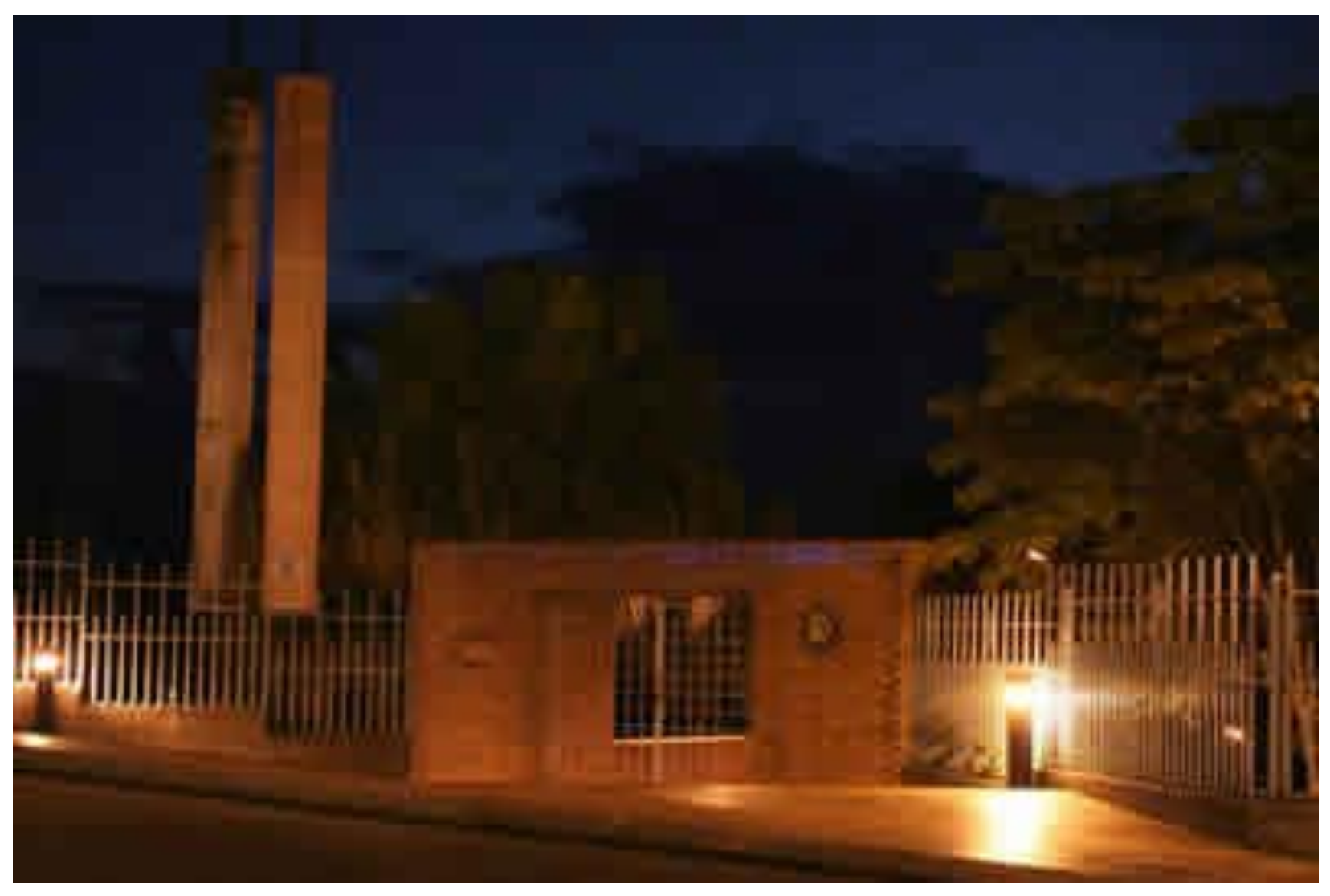

Figura 1.

Museo del Oro Quimbaya en la ciudad de Armenia. 


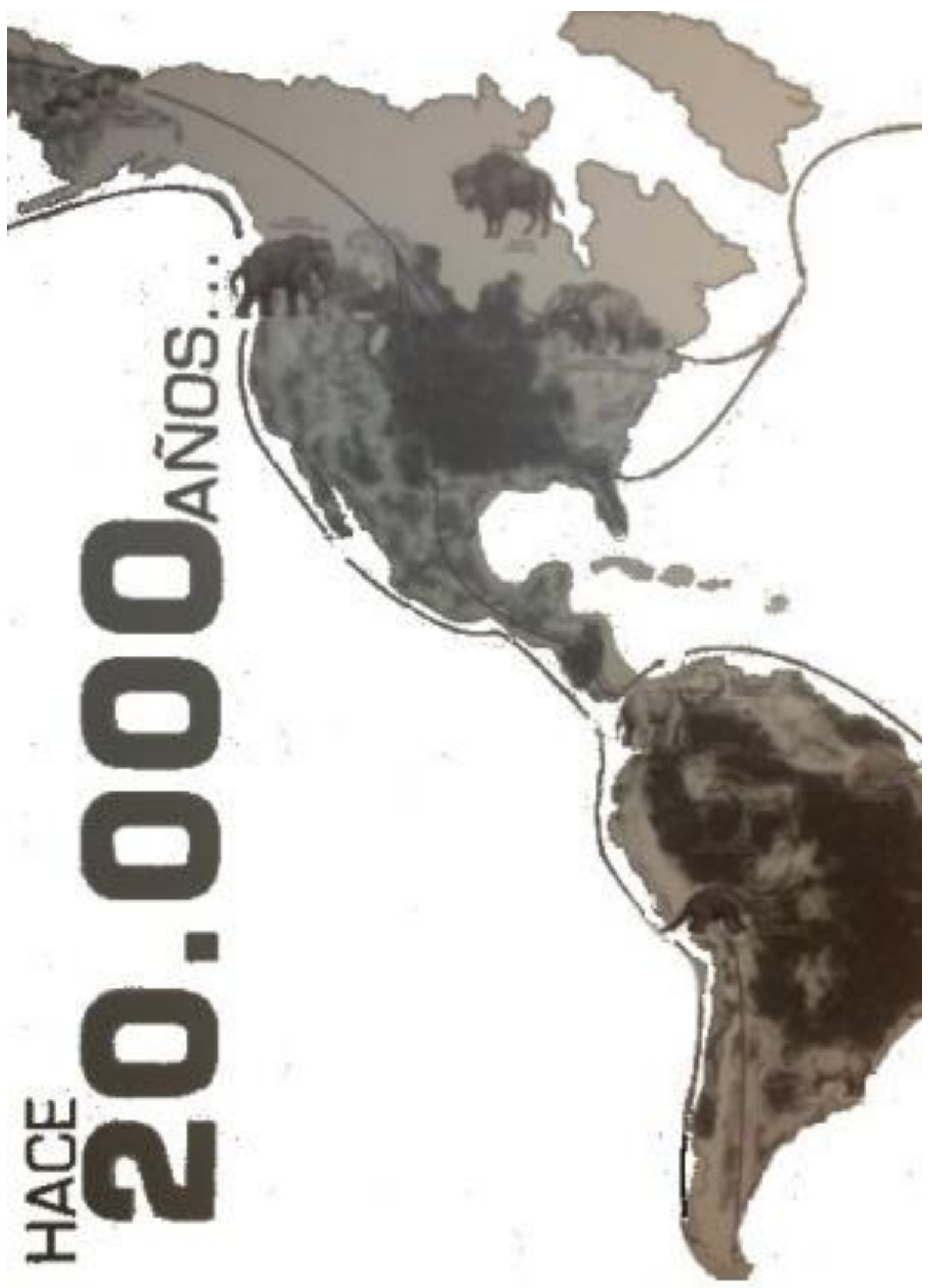


Hace 20.000 años... ¿Quiénes fueron los primeros americanos y colombianos?

Hace unos 20.000 años, grupos de cazadores provenientes de Asia llegaron por primera vez a Norteamérica. Eran los tiempos de la última glaciación, cuando amplias áreas del planeta estaban cubiertas de hielo y el nivel de los mares era más bajo que el actual, el clima era más frío y seco y deambulaban grandes animales por el territorio. Estos antiguos pobladores se internaron lentamente en el continente en búsqueda de su sustento. Cerca de 15.000 años atrás llegaron los primeros pobladores a Suramérica. Existen vestigios de grupos que cazaban venados y mamíferos pequeños, y ocasionalmente grandes animales como mastodontes y caballos americanos; también recolectaban frutos y plantas silvestres. Habitaban por temporadas bajo grandes rocas o en sitios abiertos, cerca de fuentes de agua y de alimentos. Organizados en bandas, se desplazaban durante el año por un amplio territorio siguiendo los recorridos de los animales y según las variaciones estacionales de los recursos naturales.

\section{Hace 10.000 años...}

\section{Los cazadores y recolectores en los bosques de la Cordillera Central}

Hace unos 10.000 años los glaciares retrocedieron, la temperatura y humedad del planeta subieron, los grandes mamíferos se extinguieron y la vegetación adquirió su configuración actual. Grupos de cazadores y recolectores poblaron la Cordillera Central y el suroccidente colombiano hacia esta época. Vivían de la explotación del bosque mediante la recolección, la cacería y la pesca. Consumían nueces y brotes de palmas, la nuez del nogal, frutas, tubérculos y granos. El medio les proveyó también de materiales para hacer instrumentos y objetos de su vida cotidiana. Los cazadores y recolectores comenzaron desde tiempos muy antiguos a influir en el desarrollo de plantas, y con el paso del tiempo empezaron a cultivar. La población creció, los asentamientos se hicieron más grandes y permanentes y las sociedades se transformaron.

\section{El Cauca medio, una región rica y diversa}

La región del Cauca medio se ha caracterizado por su enorme riqueza de recursos y una gran diversidad ecológica, cualidades que fueron aprovechadas por las sociedades que la habitaron. Sobresalen la exuberancia y variedad de flora y fauna, la riqueza mineral, la fertilidad de los suelos y la abundancia de ríos.

El relieve es montañoso con pendientes escarpadas, colinas redondeadas y algunas tierras planas, y está cortado por numerosos valles y corrientes de agua. Las variaciones de altitud, desde los 500 hasta los 5.400 metros sobre el nivel del mar proveen una amplia variedad de climas, desde el cálido hasta las nieves perpetuas, que, sumada a las diferencias de lluvias y los vientos, generan múltiples ecosistemas.

El paisaje del Cauca medio tiene una larga historia de transformaciones por eventos geológicas, cambios en el clima e intervenciones humanas. Aun se pueden observar en el paisaje las huellas dejadas por las sociedades del pasado.

\section{Hace 2.500 años}

\section{Las primeras sociedades agrícolas y orfebres}

Las primeras sociedades agrícolas y orfebres del Cauca Medio fueron semejantes en su forma de vida y pensamiento a otras dispersas sobre un amplio territorio en el centro de los Andes colombianos. Habitaron entre el 500 a.C. y el 600 de nuestra era, época denominada por los arqueólogos como Periodo Temprano. 


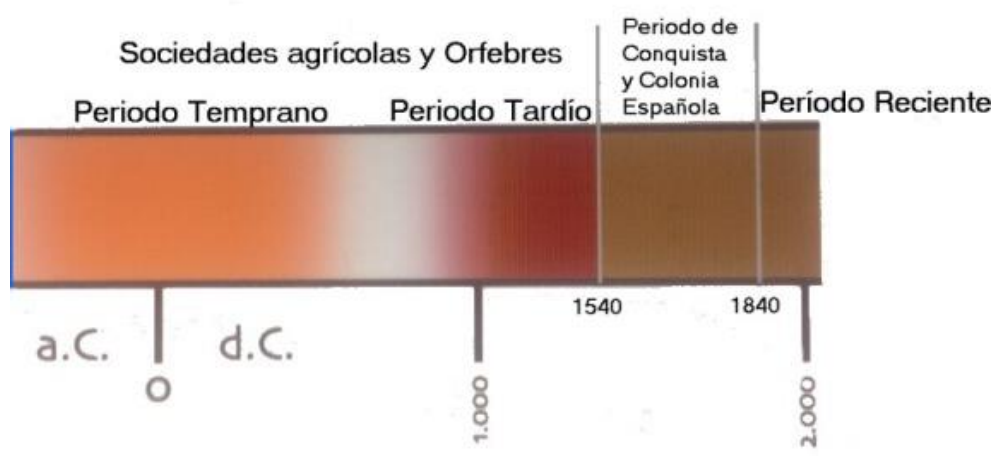

Figura 2.

Sociedades agrícolas y orfebres, desde el periodo temprano al reciente.

Estas poblaciones cultivaban la tierra y extraían oro y sal que utilizaban en el intercambio. Se dispersaron desde el piso cálido al frío, sobre planicies naturales o explanadas construidas en las laderas, cerca de ríos quebradas y humedales. Casaban, pescaban y recogían frutos silvestres, insectos y moluscos.

Estas fueron sociedades jerarquizadas, quizá organizadas en cacicazgos, en las cuales los jefes cumplían funciones políticas y religiosas. Jefes, orfebres y tal vez otros artesanos tenían oficios especializados. Los orfebres elaboraron los objetos de calidad excepcional conocidos como orfebrería Quimbaya.

Vasijas como las de la figura 3 eran utilizadas en la explotación de la sal y como urnas cinerarias. La sal se extraía en manantiales de agua salina. El líquido se hervía en grandes vasijas de cerámica que se rompían para extraer la sal decantada.

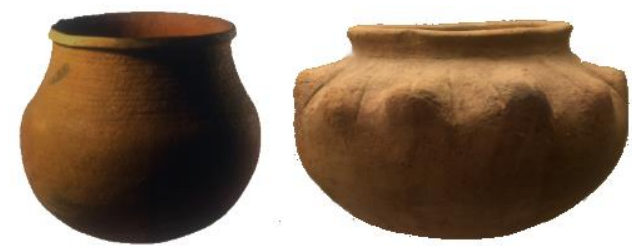

Figura 3.

Vasija para explotación de sal y urna cineraria, que imita una calabaza

\section{¿Por qué las piezas de la orfebrería Quimbaya son rosadas y brillantes?}

Los orfebres de estas sociedades elaboraron adornos corporales, objetos para el consumo de las hojas de coca, instrumentos musicales y herramientas. La mayoría de las piezas fueron fabricadas para uso de los jefes y luego enterradas con ellos. Estos objetos reforzaban su prestigio y les daban poderes para propiciar fertilidad y el equilibrio.

Las formas más frecuentes en las piezas eran las de figuras femeninas, calabazas, calabazos y totumas, que eran símbolos de reproducción, fertilidad y vida. Las superficies brillantes y rosadas de la tumbaga, aleación de oro y cobre, tenían significados relacionados con estas mismas ideas. Para algunos indígenas colombianos el oro es un elemento masculino, y el cobre, femenino: en la tumbaga se unen ambos principios. Creen también que los objetos brillantes están cargados de poderes espirituales y sagrados.

Los orfebres ocuparon una posición destacada en la sociedad. Sus conocimientos tecnológicos y el poder de transformación de los metales pudieron ser fuente de prestigio y estimación especial. En muchas culturas se los consideró "Señores de Fuego", de condición superior y ascendencia divina. 


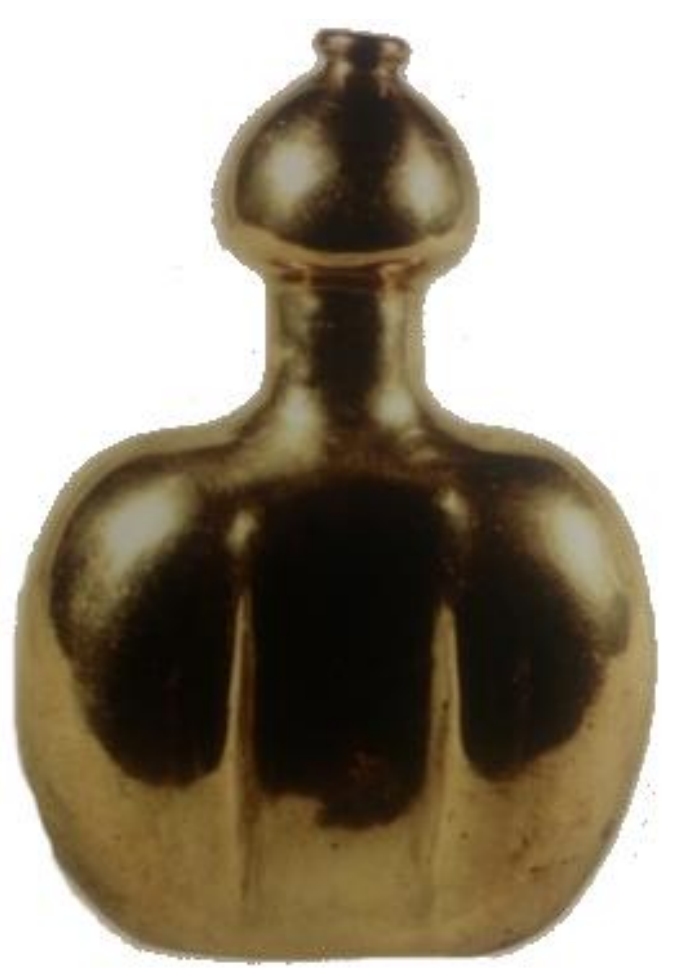

Figura 4.

Recipiente para cal, en forma de calabazo estilizado, elaborado en tumbaga, procedente de Quimbaya, Quindío y perteneciente a la Colección del Museo de Berlín, Alemania.

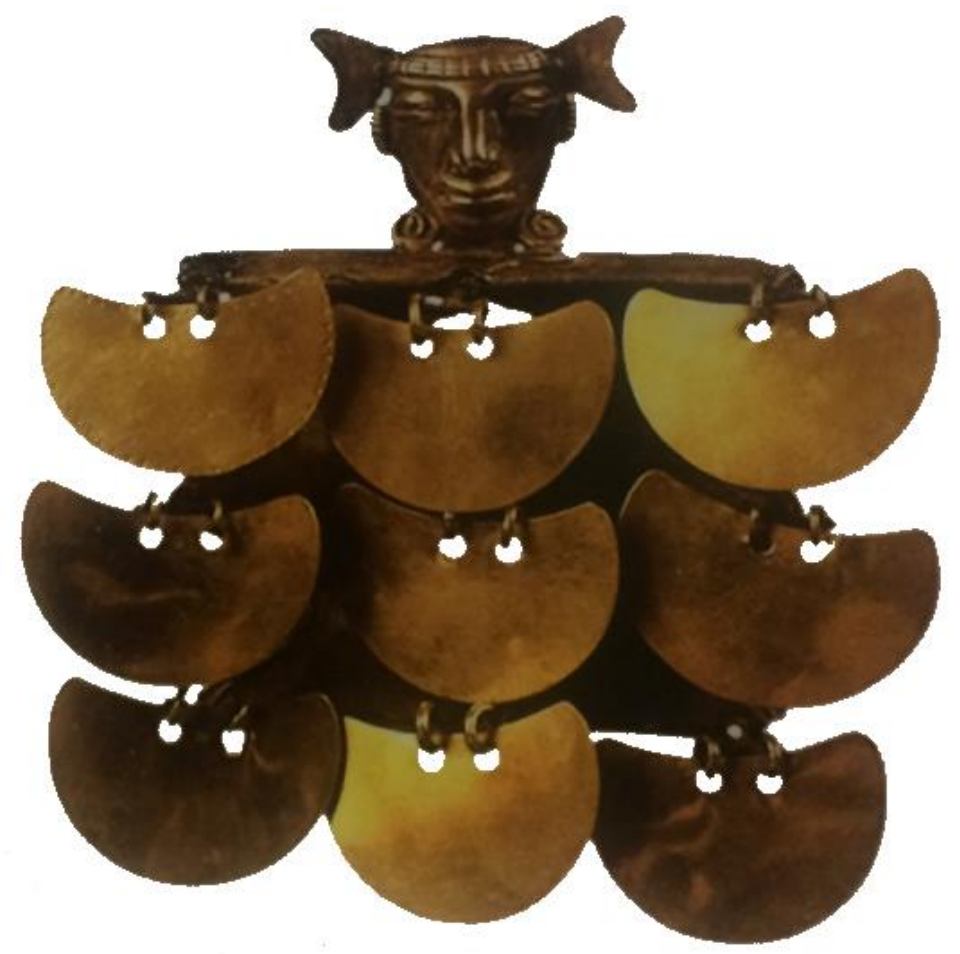

Figura 5.

Adorno colgante en forma de figura humana con el cuerpo oculto por placas colgantes. Encontrado en Trujillo, Valle del Cauca. Colección Museo del Oro, Bogotá. 


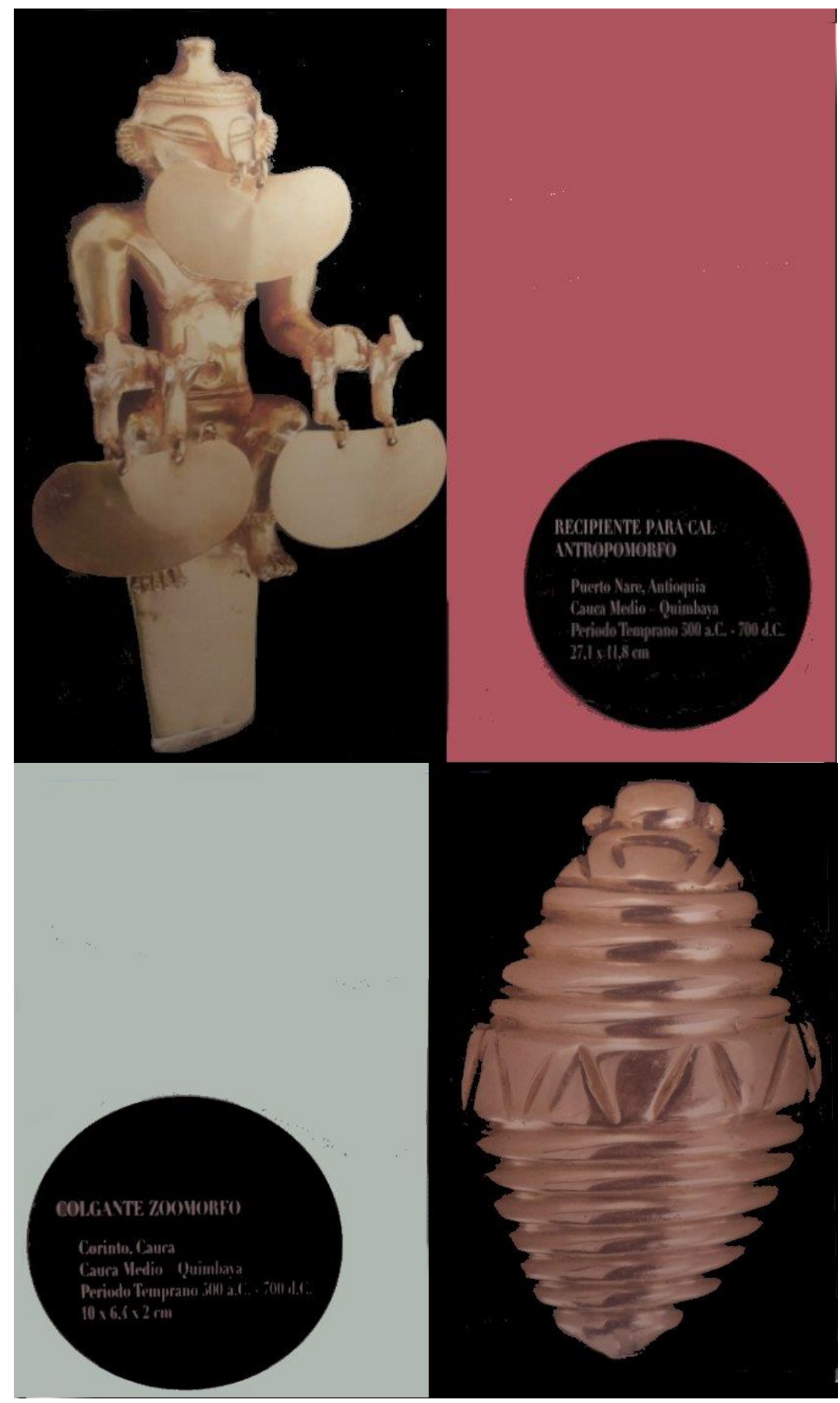



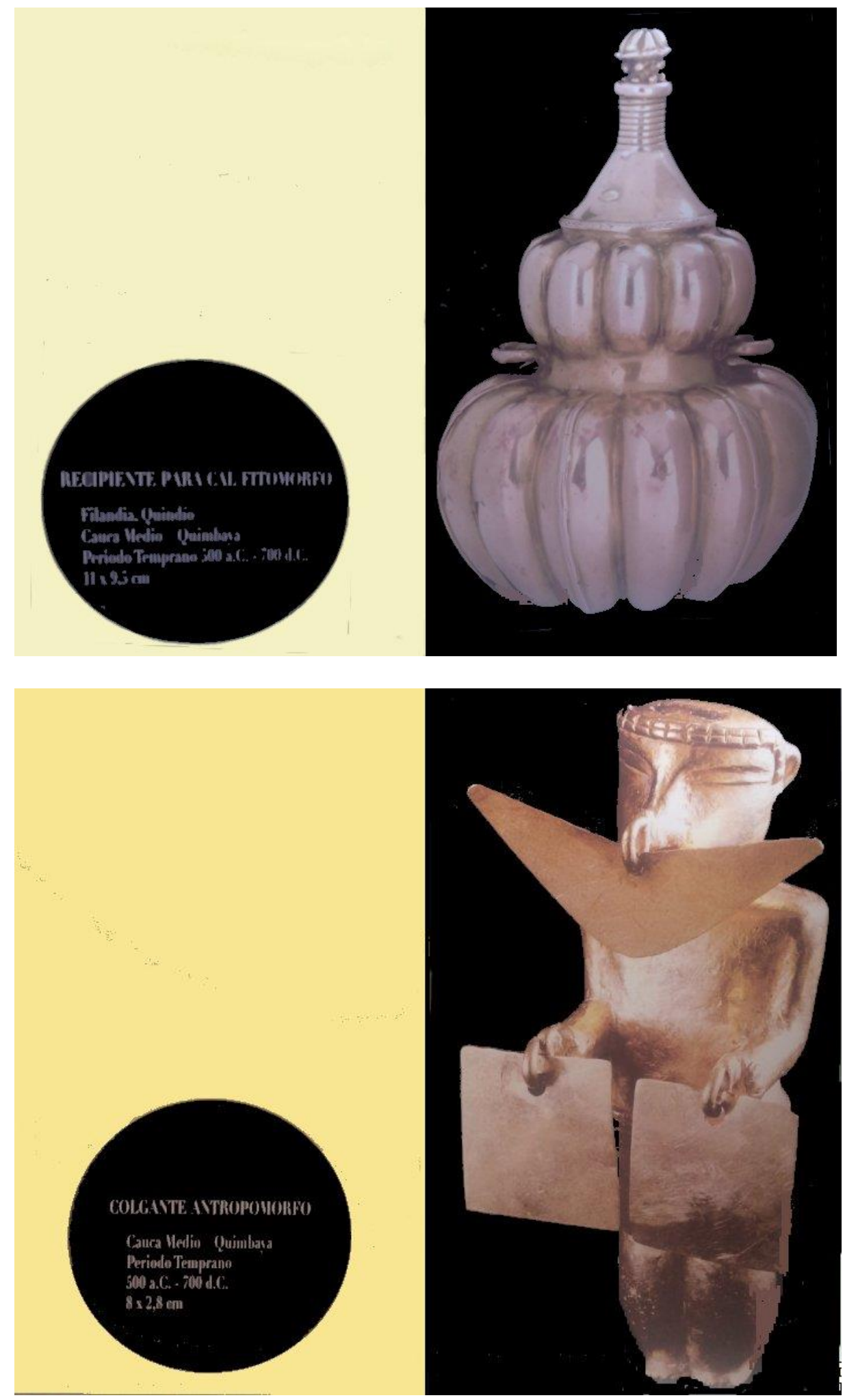

\section{Una visión en espiral de la vida y la muerte}

Estas sociedades incineraron a sus muertos y depositaron sus cenizas en urnas de cerámica que enterraron dentro de fosas irregulares y poco profundas, ubicadas en el área de las viviendas o en sus cercanías. Dentro de las urnas se han encontrado los restos de uno o varios 
individuos. A su alrededor colocaron vasijas de cerámica doméstica, y en ocasiones, objetos de orfebrería. La calidad de la urna y de la ofrenda dependía del rango y otras características del muerto.

La costumbre de incinerar el cadáver tiene en varias culturas el significado de trasladar el muerto a un estado inicial para que nazca de nuevo. Las urnas que representan mujeres embarazadas, usadas por estos grupos, sugieren esta visión en espiral de la vida y la muerte.
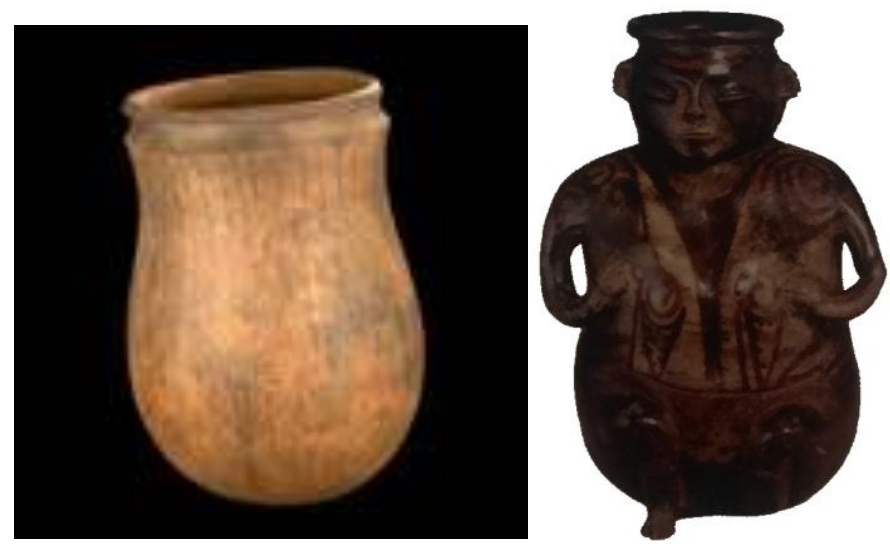

Figura 6.

A la derecha, urna cineraria en forma de mujer embarazada dando a luz. Colección Museo Universitario, Universidad de Antioquia, Medellín.

\section{Los entierros de los jefes}

Los jefes y otros personajes de alto rango fueron enterrados en tumbas especiales con algunos de sus bienes. El conocido "Tesoro de los quimbayas", un hallazgo con cerca de 200 piezas de orfebrería y un número desconocido de cerámicas, estaba compuesto por los ajuares funerarios de varios líderes sepultados en dos tumbas en el sitio de La Soledad, en Quimbaya, Quindío.

Parte del "Tesoro" fue comprado en 1891 por el Gobierno colombiano para ser expuesto en Madrid en la conmemoración del IV Centenario del Descubrimiento. Infortunadamente para el patrimonio cultural del país, fue obsequiado luego a la Corona española. Hoy se exhibe en el Museo de América de Madrid. Según una fecha de radiocarbono, los objetos de orfebrería del "Tesoro" fueron elaborados hacia el 250 d.C.

En 1987 fue descubierto otro gran ajuar con 16 piezas excepcionales de orfebrería Quimbaya en Puerto Nare, en la región del Magdalena medio antioqueño. La mayoría de estos objetos se conservan en la Colección del Museo del Oro del Banco de la República y varios de ellos están expuestos en este museo.

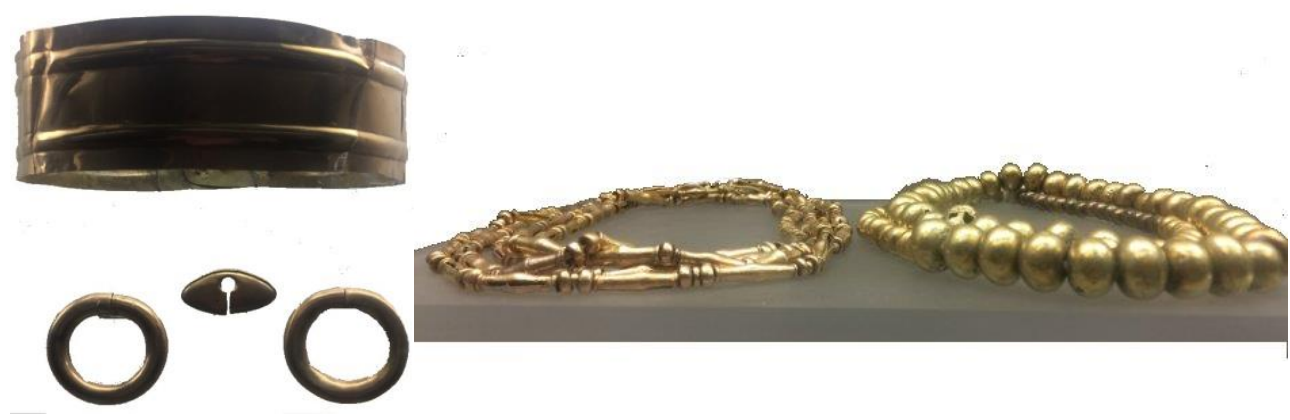




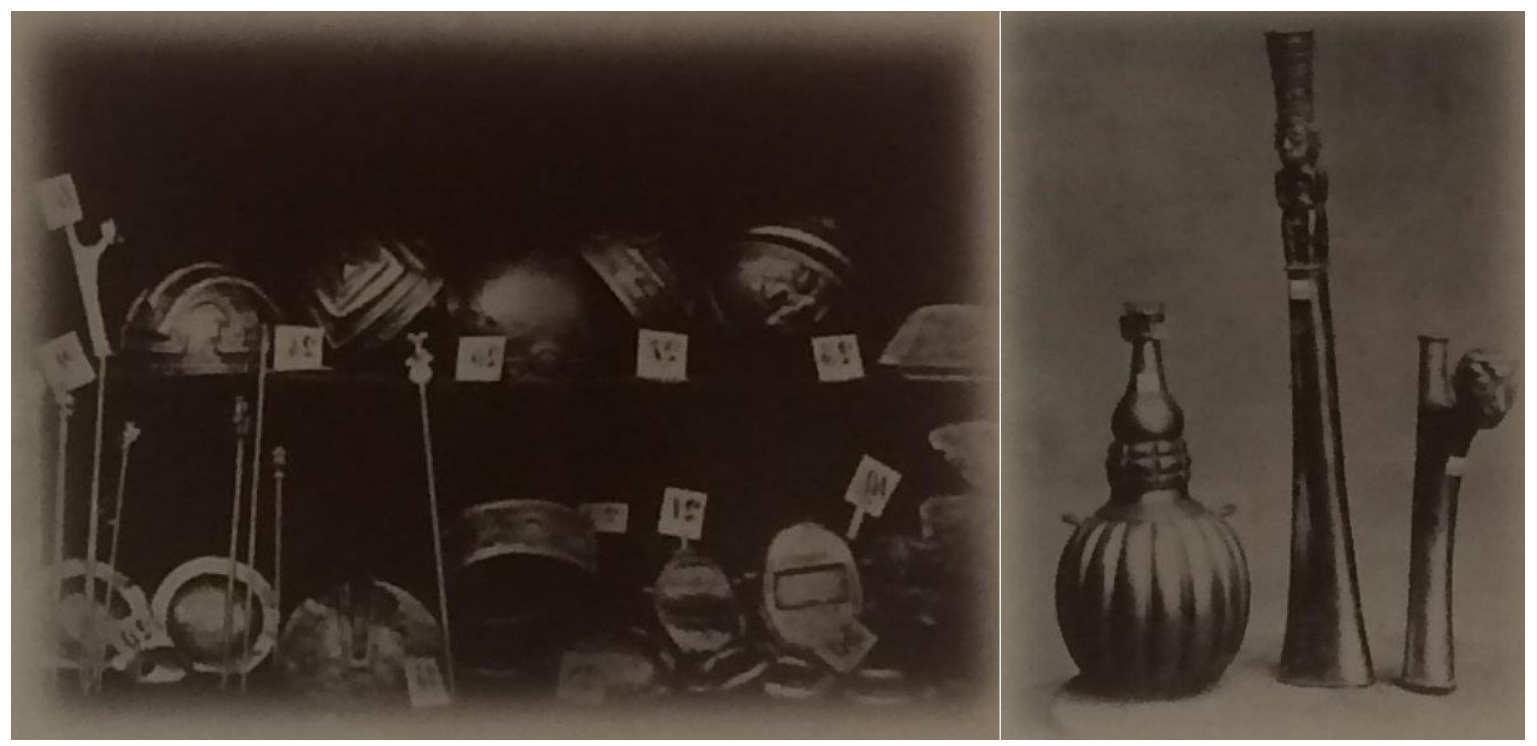

Figura 7.

Fotografía de Catálogo del Tesoro Quimbaya en 1891. A la izquierda, imagen del catálogo con el cual se ofrecieron al gobierno colombiano las piezas del Tesoro Quimbaya por parte de un coleccionista de arte. La imagen corresponde al catálogo que acompañó la muestra colombiana en la exposición Histórico Americana de Madrid en 1892.

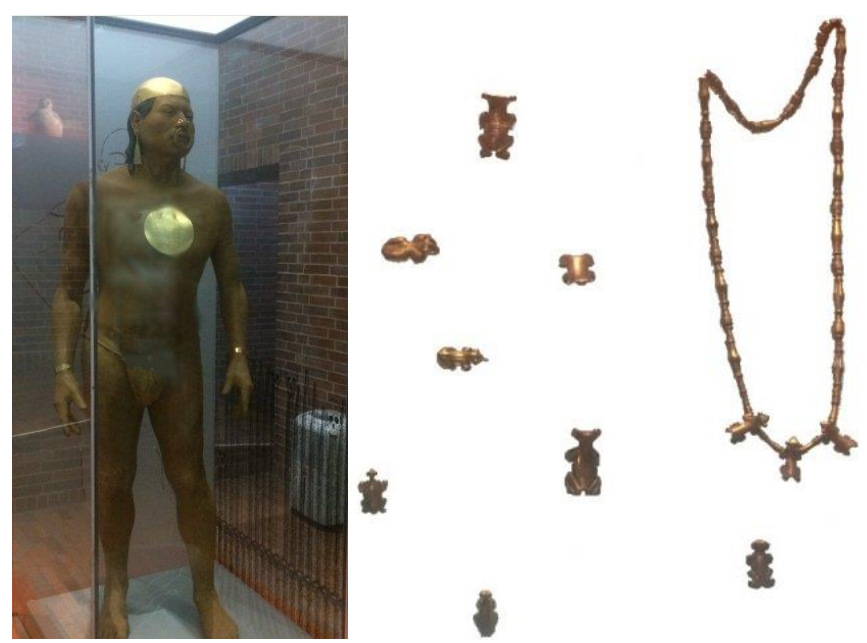

Figura 8.

Cacique. La rana y su metamorfosis tuvieron atractivo simbólico. 

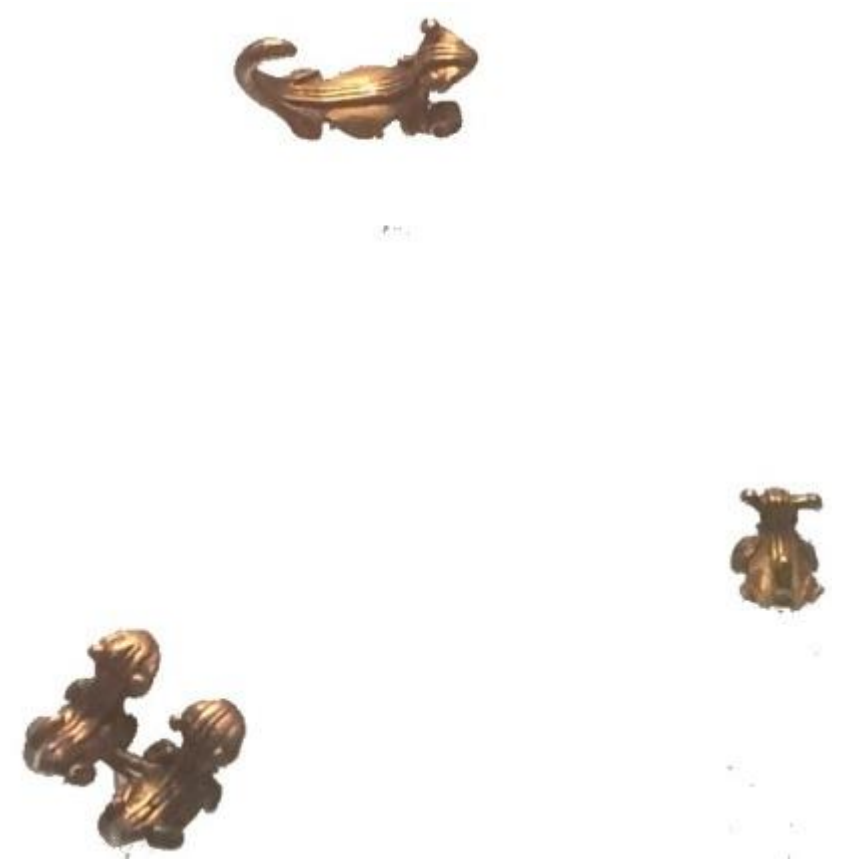

Figura 9.

Cuentas en forma de cuadrúpedos.
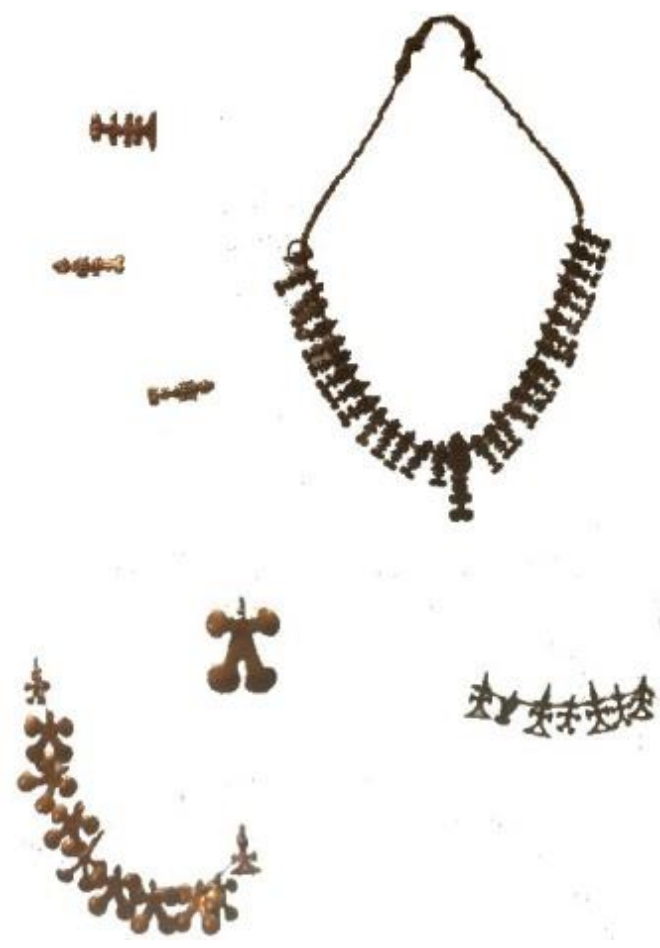

Figura 10.

Cuentas en forma de animales simulando insectos. 

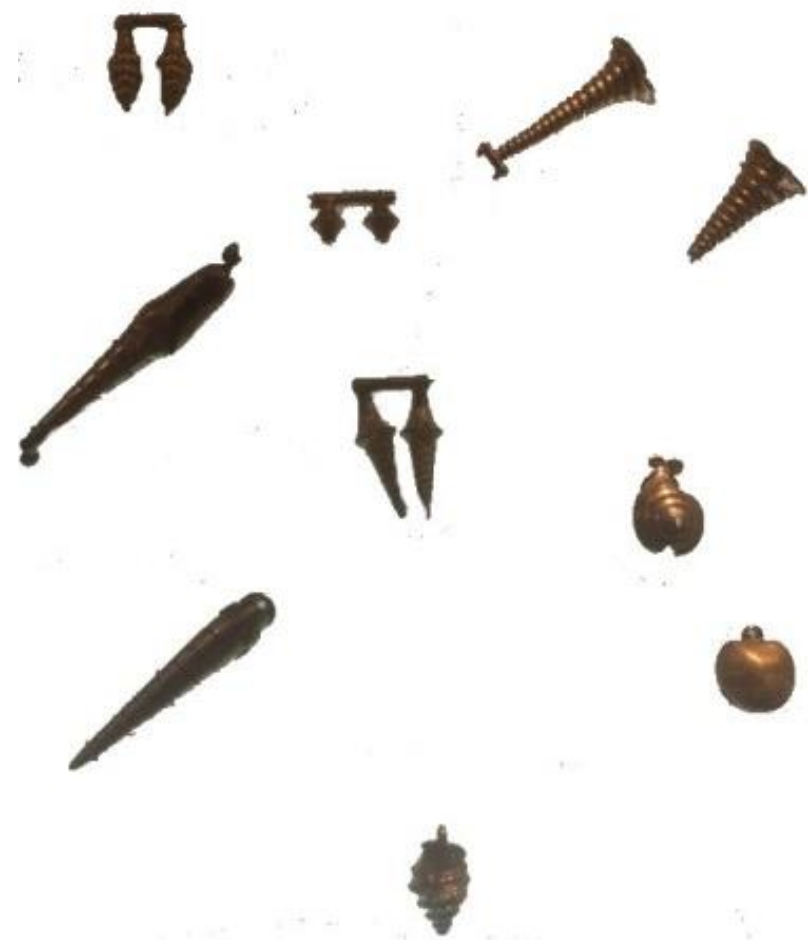

Figura 11.

Caracoles marinos y terrestres. Los caracoles representaron metáforas de ideas aún desconocidas.

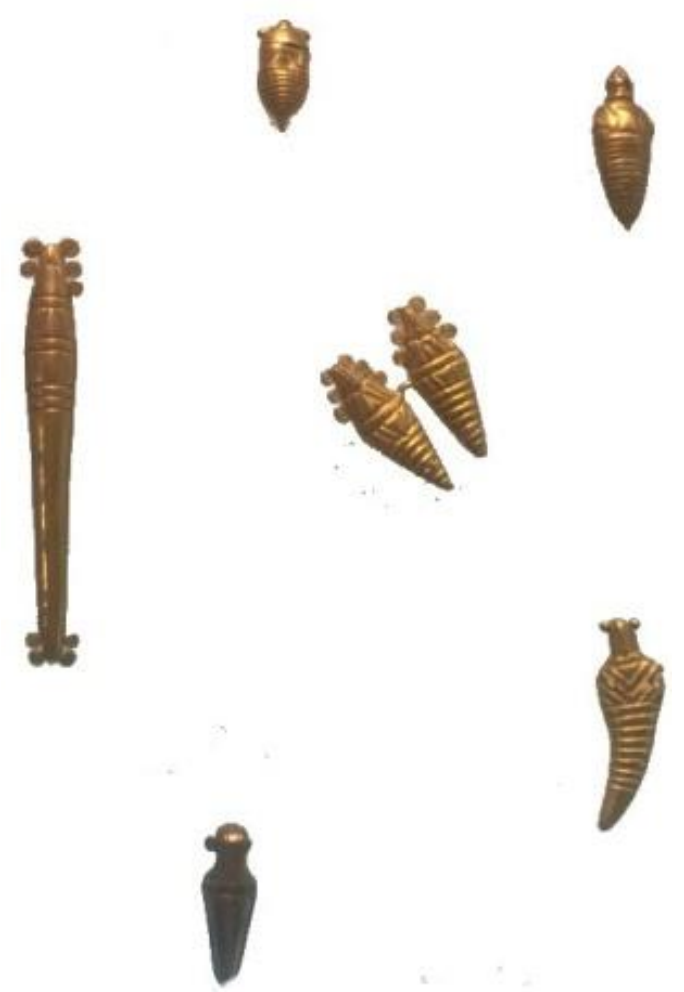

Figura 12. 
Insectos en estado de metamorfosis. La mayoría evocan pupas de mariposa, presentes en la orfebrería fueron tal vez símbolos de cambio.
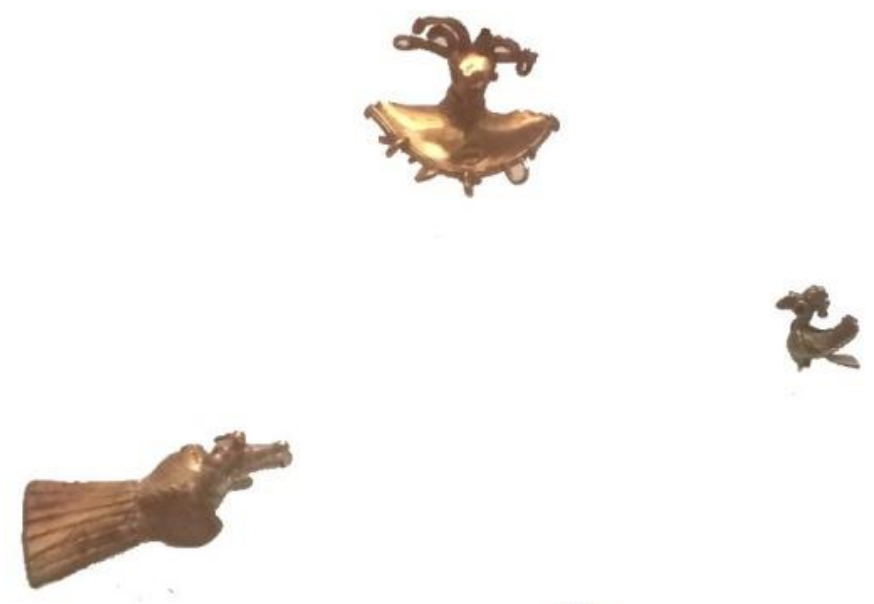

Figura 13.

El paujil fue el ave más representada en la orfebrería y la cerámica. Se caracteriza por una cresta rizada hacia adelante y una cola larga y plana.
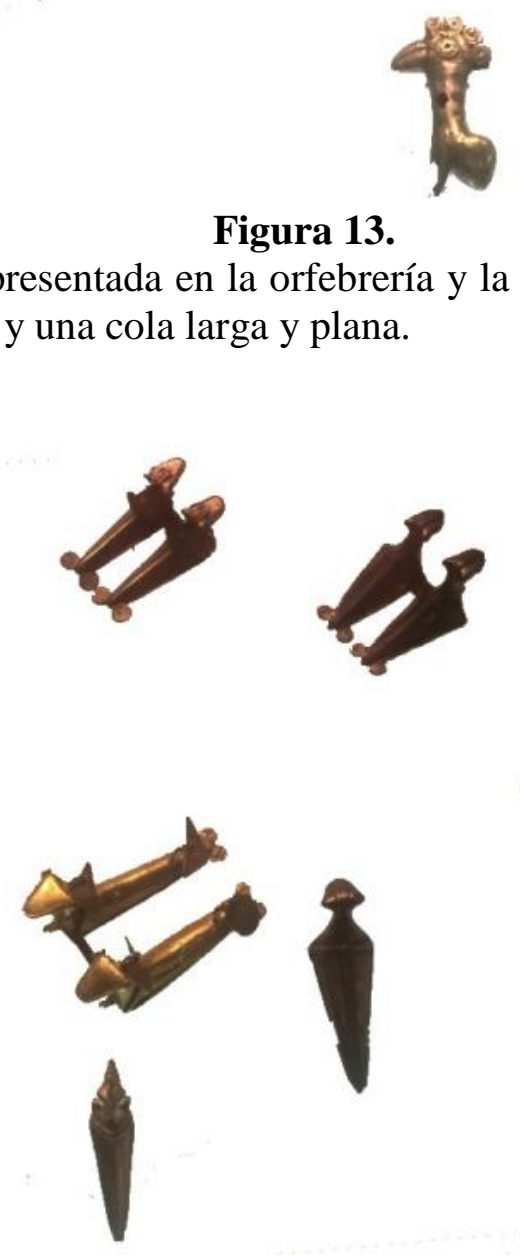

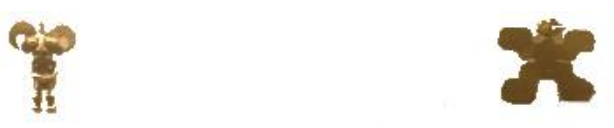

\section{裳}
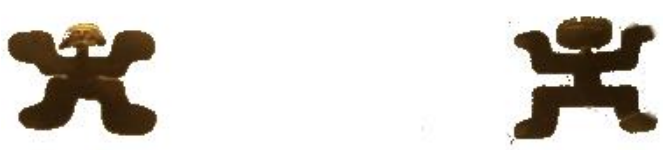

Figura 15.

Orfebrería con objetos martillados.

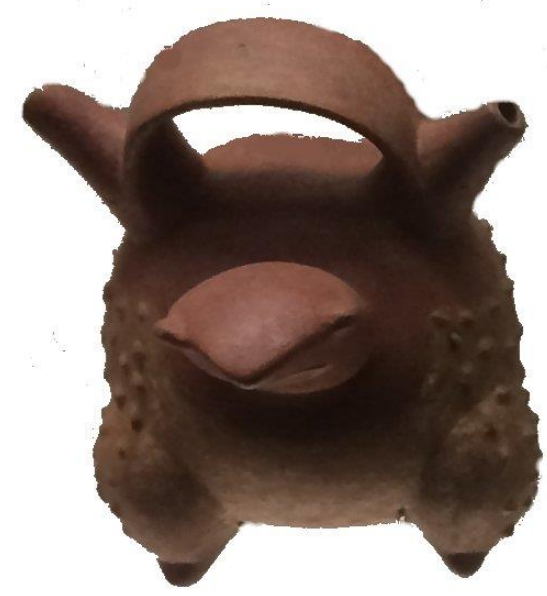

Figura 16.

Alfarería con alcarraza en forma de ave.

\section{Mensajes escritos en el cuerpo}

Estas sociedades representaron figuras humanas en cerámica, metal y piedra, y en ellas sus costumbres relacionadas con el cuerpo. La pintura corporal, los adornos, el peinado, las deformaciones intencionales de las extremidades y el limado de los dientes, fueron medios usados por estos grupos para transformar su cuerpo y expresar mensajes.

En las sociedades humanas las prácticas corporales suelen comunicar ideas acerca de la identidad étnica, el grupo familiar, el sexo, la edad, el rango social, el oficio y otras características del individuo. 


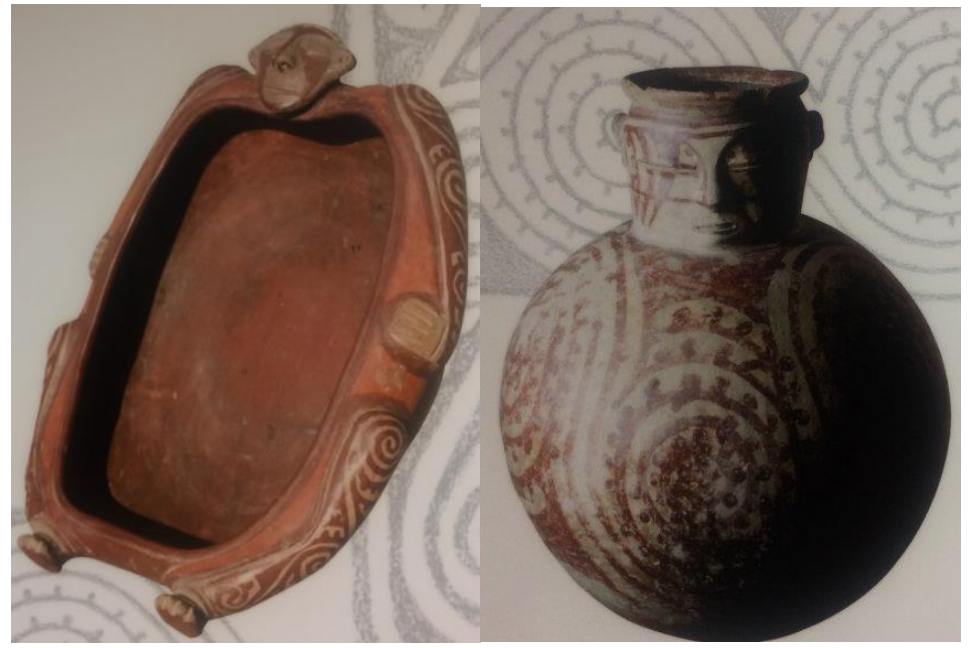

Figura 17.

La vasija de la izquierda, con forma de mujer con el rostro y el cuerpo pintados en diseños de color rojo, es de la Colección Fondo de Promoción de la Cultura, Banco Popular, Bogotá. La urna cineraria de la derecha, con representación de diseños de pintura para la cara y el cuerpo, con espirales entrelazadas, hace parte de la Colección Museo Universitario, de la Universidad de Antioquia, en Medellín.
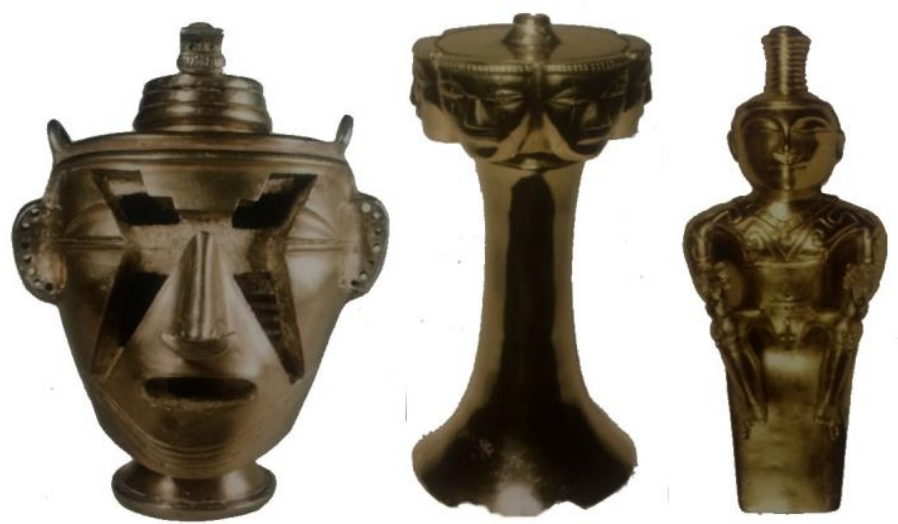

Figura 18.

A la izquierda, vasija usada para guardar la cal, se dejaron orificios para fijar incrustaciones en otros materiales que representan la pintura facial. Procede de Quimbaya, Quindío. Colección Museo de América, Madrid. Al centro, recipiente para cal con cuello decorado con rostros humanos en los que se observan líneas de pintura. En algunas vasijas de cerámica estas líneas son de color rojo. Colección Museo Británico, Londres. A la derecha, recipiente para cal con forma de hombre sentado en el cual se representó la pintura facial y corporal. Colección Museo Etnográfico, Berlín. 


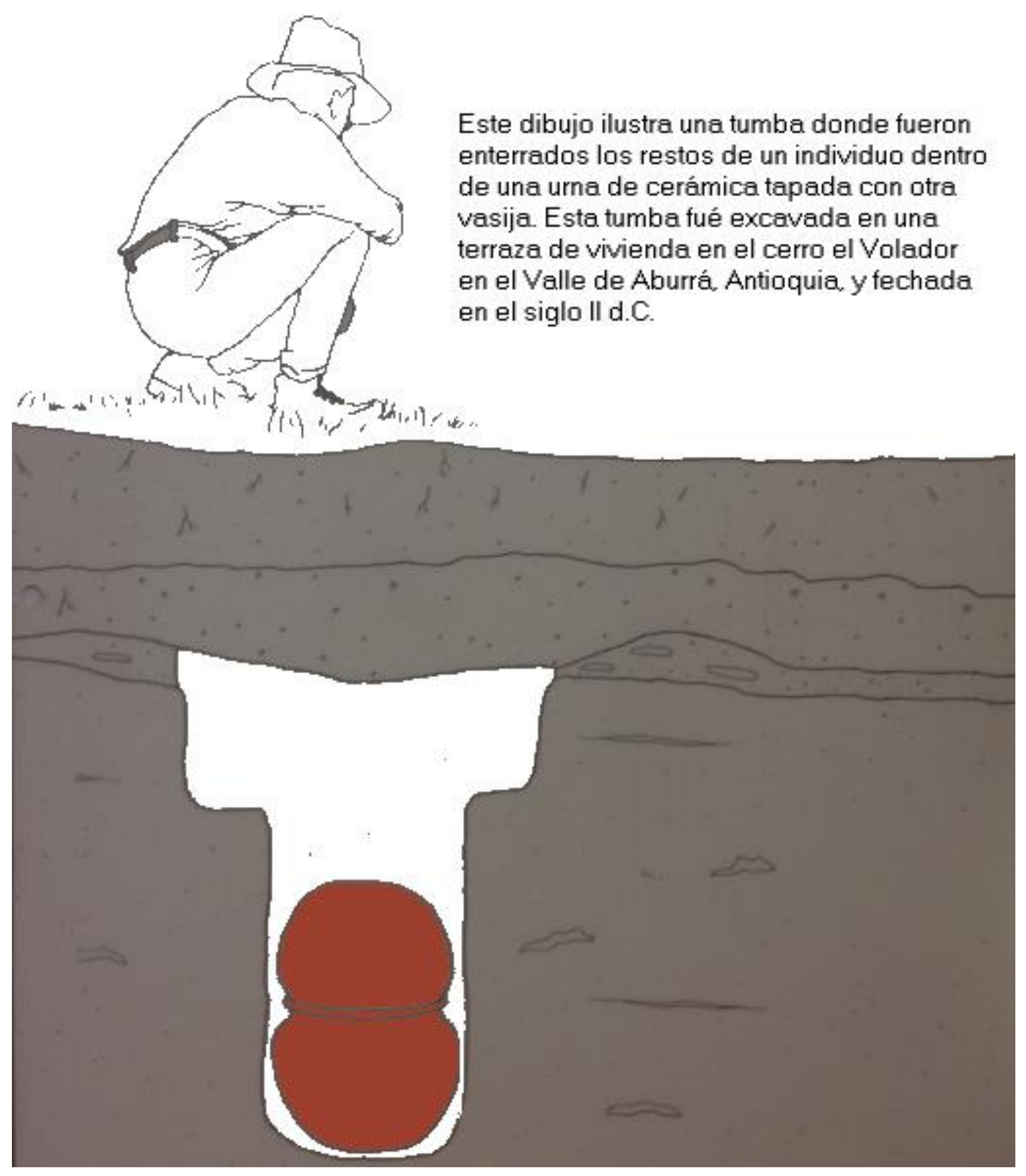



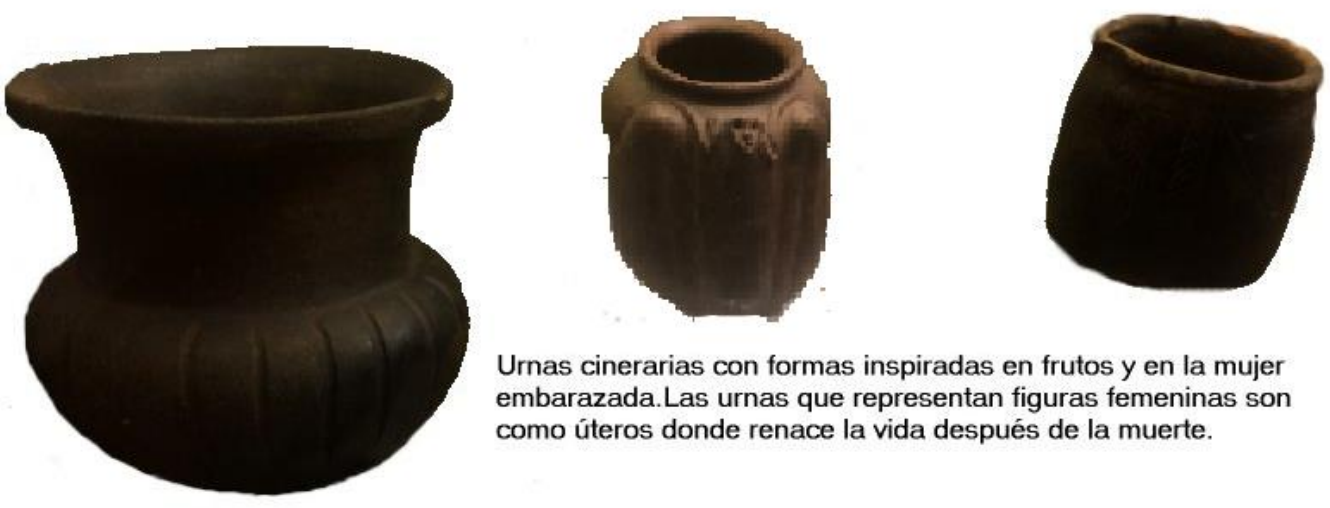

Urnas cinerarias con formas inspiradas en frutos y en la mujer embarazada.Las urnas que representan figuras femeninas son como úteros donde renace la vida después de la muerte.

\section{Metalurgia}

\section{¿Cómo fabricaron los orfebres estos objetos?}

En la América prehispánica los objetos metálicos fueron símbolos relacionados con la religión, el poder y la sociedad. El color, el brillo, el sonido y el olor eran las propiedades más valoradas del metal. Los artífices de la orfebrería Quimbaya fueron maestros en el manejo de las aleaciones de oro y cobre para conseguir diferentes colores y dominaron las técnicas de pulimento con las que lograban superficies brillantes.

\section{La fundición a la cera perdida}

La fundición a la cera perdida fue el proceso básico utilizado por estos orfebres en la fabricación de la mayoría de sus piezas. Las cuentas de collar en forma de rostro humano fueron elaboradas con esta técnica.

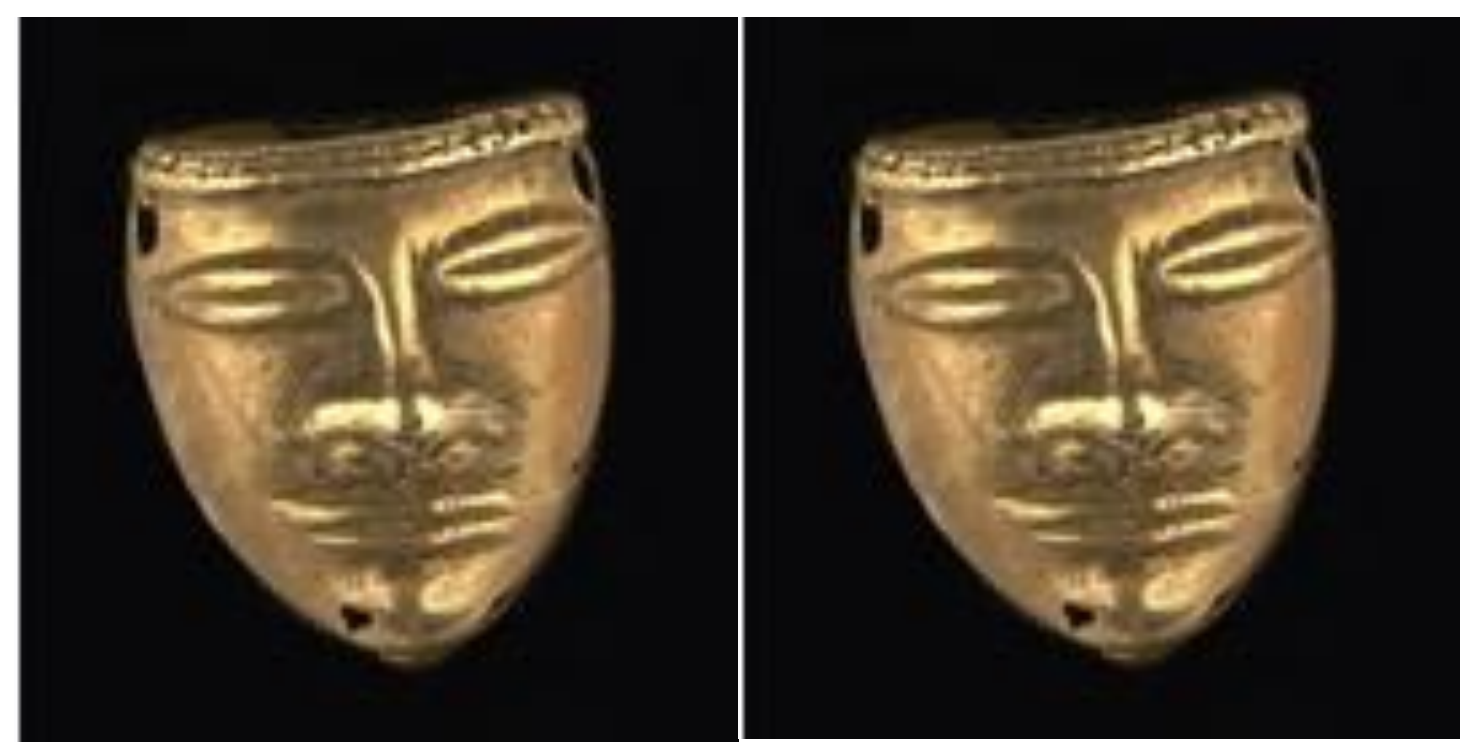

Figura 19.

Cuentas de collar en forma de rostro humano. 


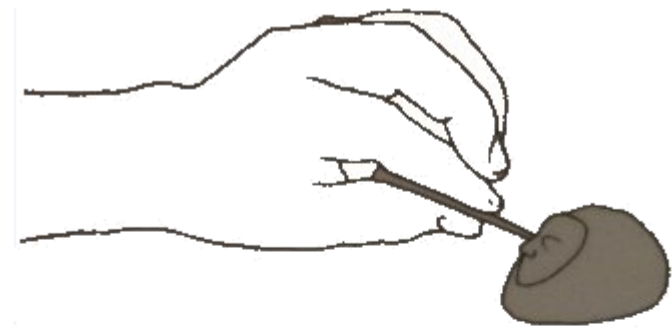

1. El orfebre tallaba el diseño de la pieza en una matriz de arcilla y carbón vegetal molido

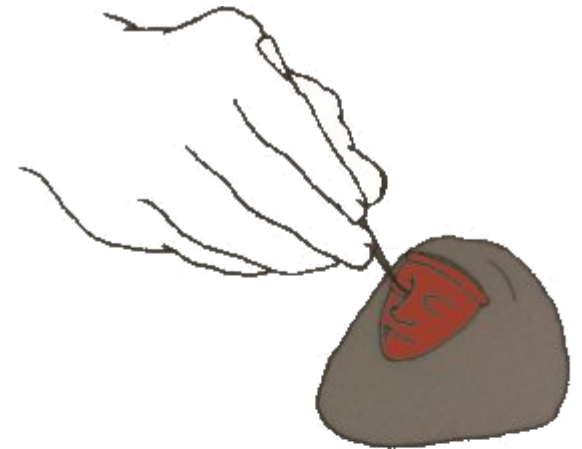

2. Encima colocaba una lámina delgada de cera de abejas. que recortaba del tamaño de la pieza y la colocaba sobre ella. Tallaba y aplicaba los detalles externos adicionales.

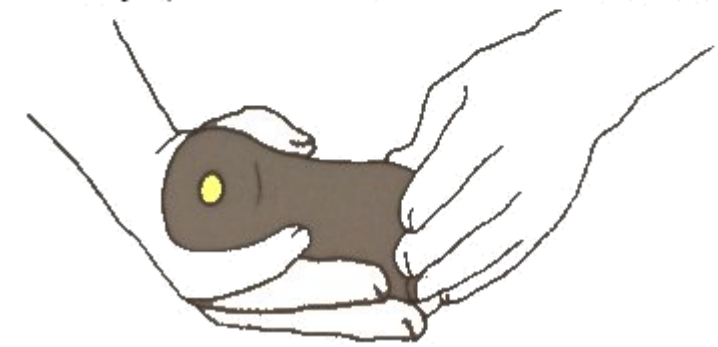

4. Recubría todo el modelo con una capa o molde de arcilla, dejando libre la parte superior del embudo.
3. Le añadia un embudo de cera por el que vertería luego el metal líquido (oro o tumbaga)

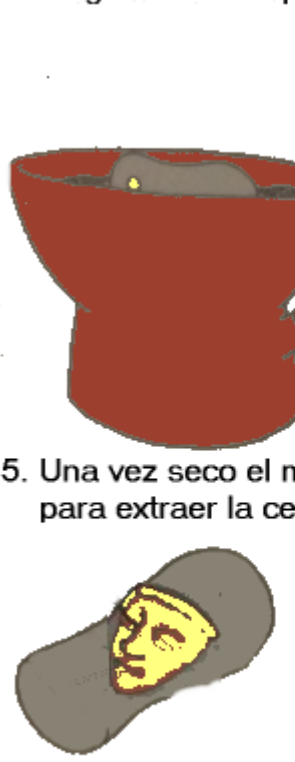
lo rompía para extraer la pieza. El molde, antes de cera, ahora era metal

FUENTE: Museo de Oro Quimbaya, Armenia Quindío. Edición de textos e imágenes: Jorge Hernán Velásquez Restrepo. Noviembre 13 de 2.017
6. Derretía el metal dentro de un crisol o recipiente refractario de cerámica o carbón, colocado entre las brasas en una hornilla de cerámica. Vertía el metal líquido en el molde caliente.
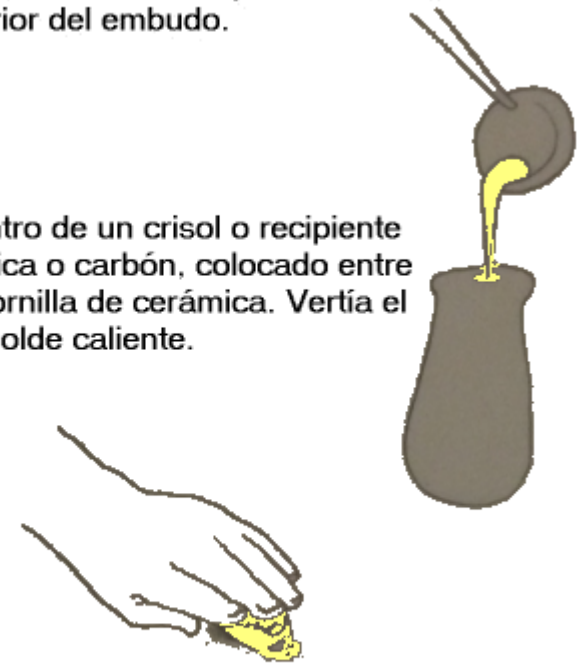

Figura 20.

Fundición a la cera perdida. 


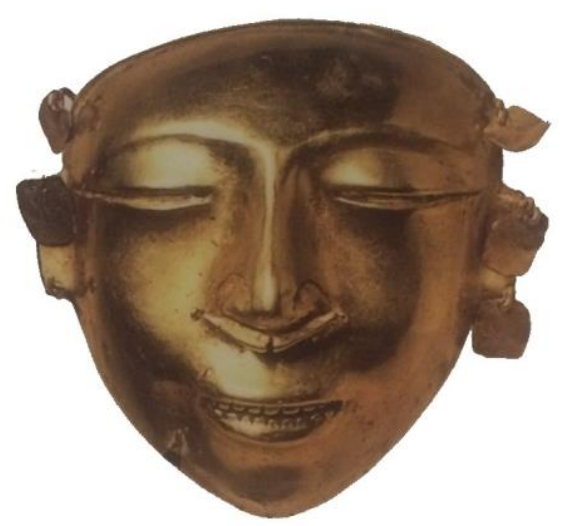

Figura 21.

Colgante de rostro humano.

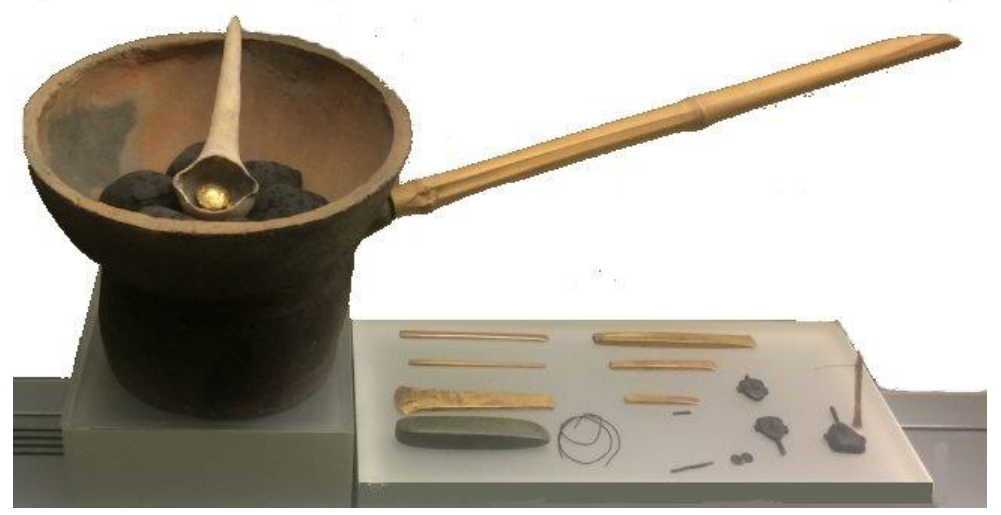

Figura 22.

Hornilla de cerámica y guadua, con cinceles de metal y piedra.

\section{Los recipientes de metal fueron hechos con núcleo}

Estos orfebres fueron maestros en la elaboración de piezas huecas mediante la técnica de la fundición a la cera perdida con núcleo. En la fabricación de los recipientes para guardar la cal siguieron este proceso: 


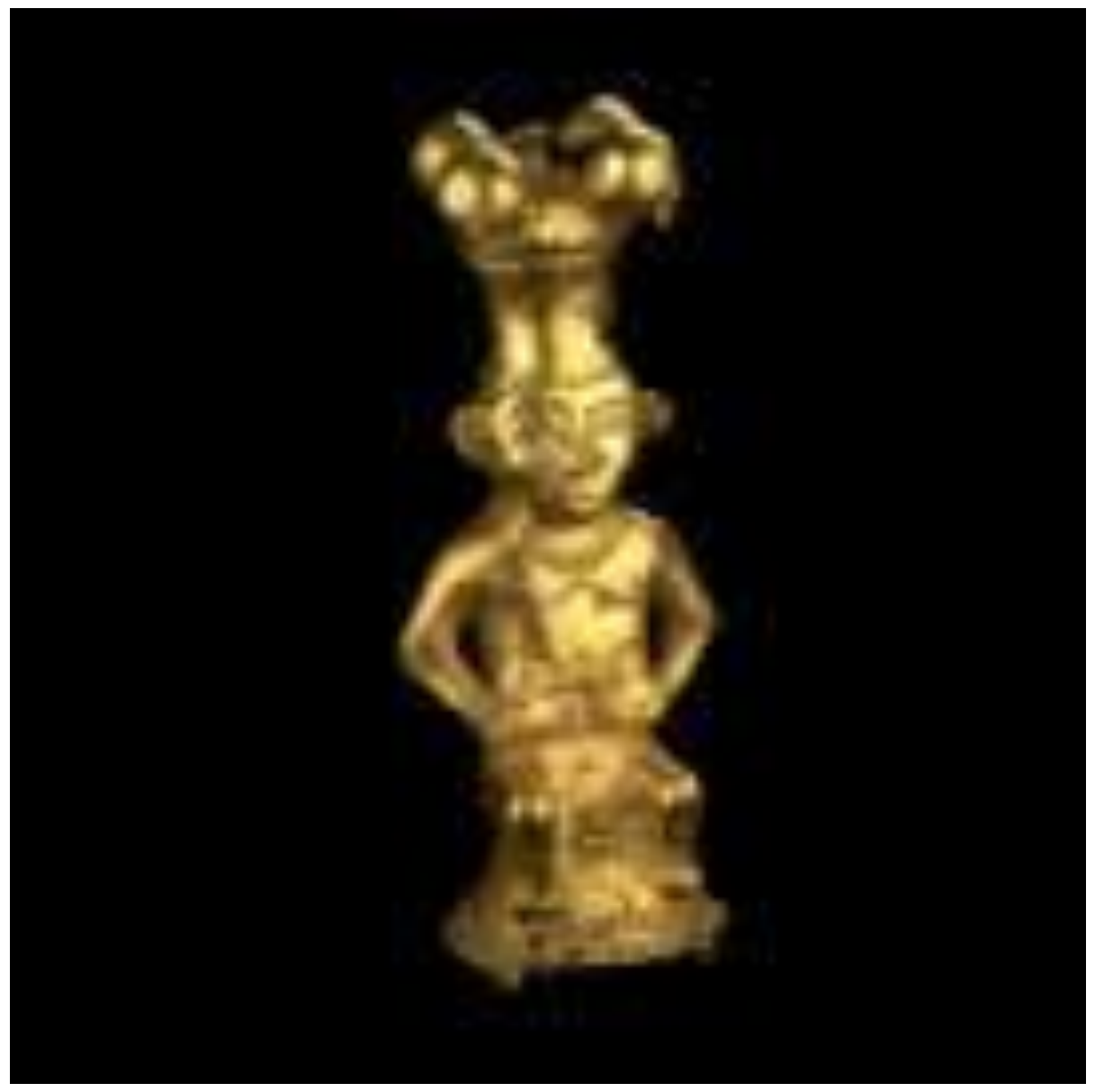

Figura 23.

Pieza hueca elaborada mediante fundición. 

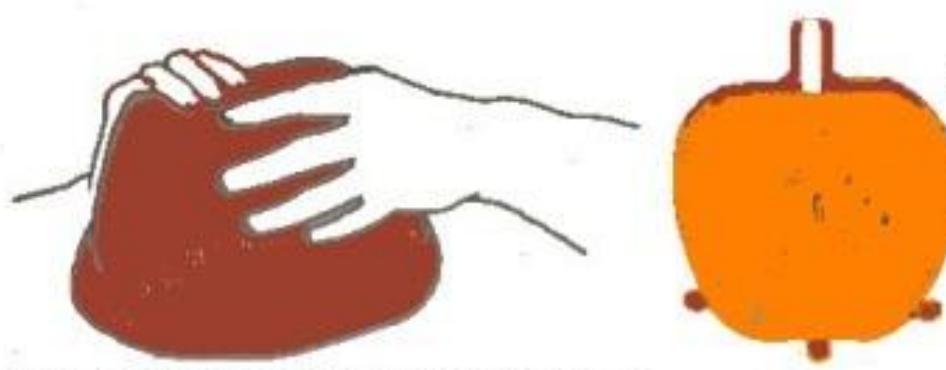

2. Lo cubría con una capa de cera a la cual adicionaba un embudo. Colocaba varios soportes para mantener el núcleo durante la fundición

1. El orfebre modelaba el núcleo con la forma de la pieza en una mezcla de arcilla y carbón vegetal molido

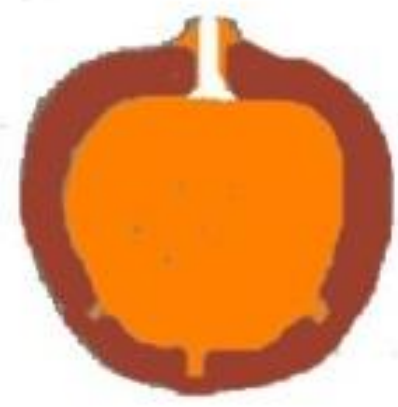

3. Recubría el núcleo con una cubierta o molde de arcilla

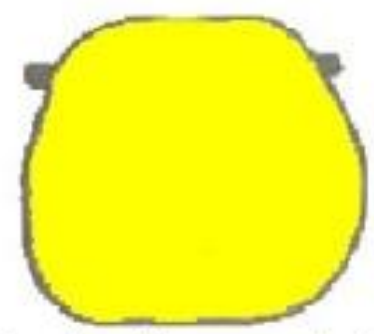

5. Rompía el molde y extraía los soportes y el material del núcleo. Los orificios de los soportes los reparaba con tapones o remaches del mismo metal que disimulaba puliéndolos.

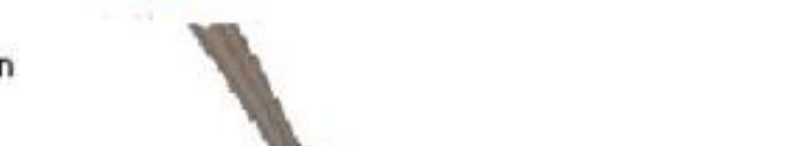

4. Vertía el metal en el molde previamente calentado y retirada
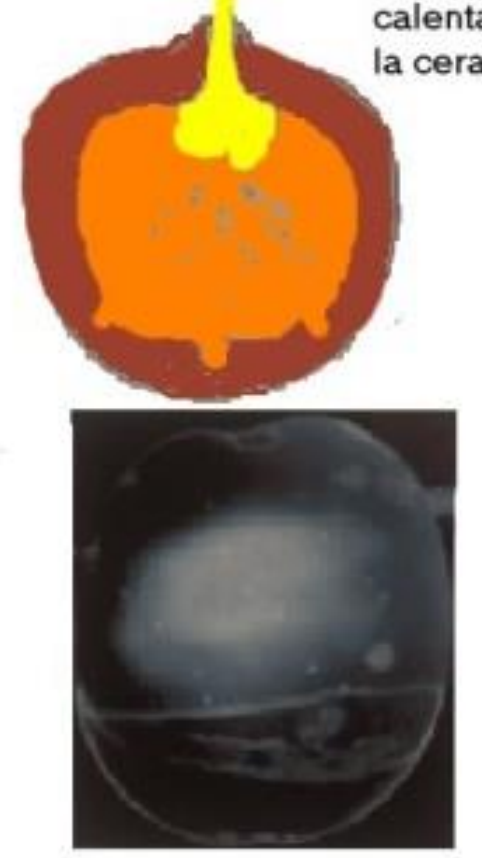

La gamagrafia revela los orificios en donde fueron insertados los soportes del núcleo en la parte central del recipiente

Figura 24.

Fabricación de recipientes para guardar la cal.

\section{Los orfebres trabajaron también piezas martilladas}

Los orfebres de estos grupos dominaron también el martillado y el repujado. Estas técnicas requieren de una gran destreza artesanal y un profundo conocimiento del comportamiento de los metales. 

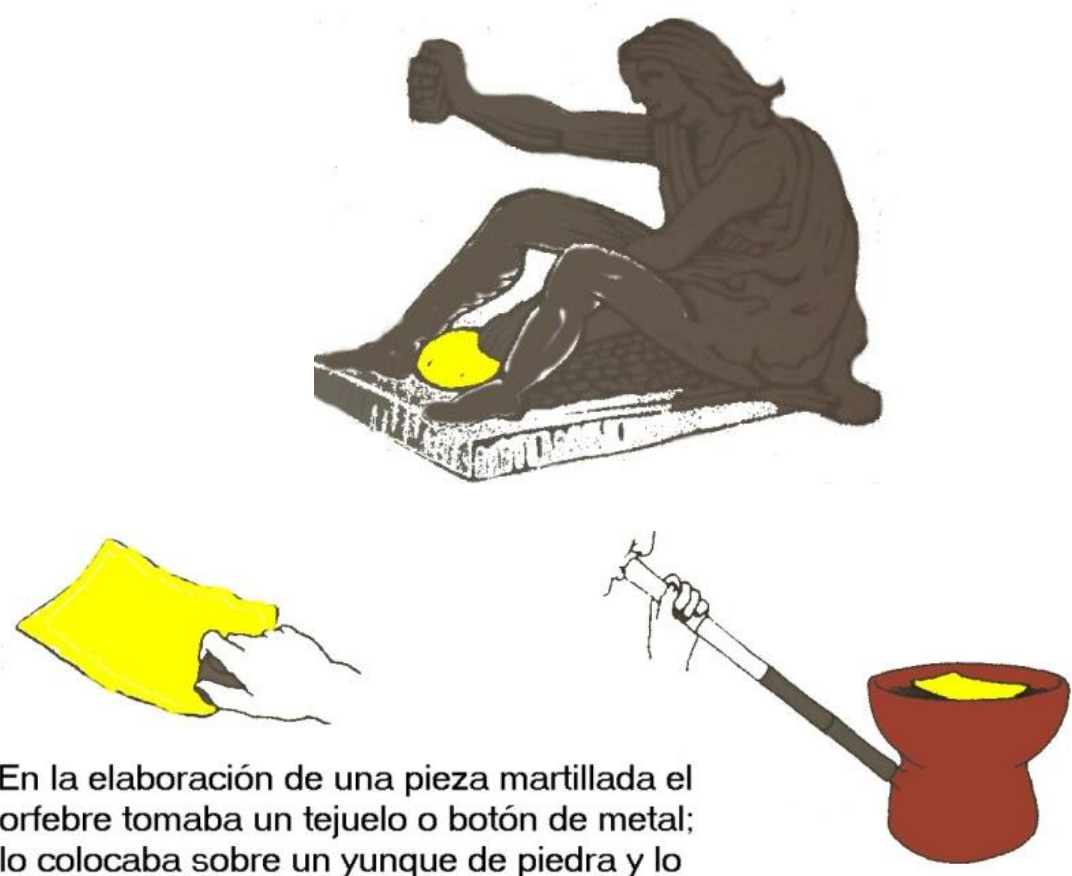

1. En la elaboración de una pieza martillada el orfebre tomaba un tejuelo o botón de metal; lo colocaba sobre un yunque de piedra y lo golpeaba hasta conseguir la lámina

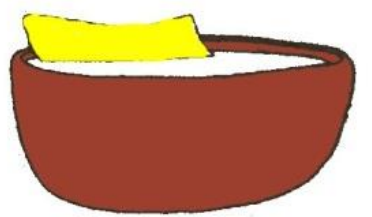

2. El metal se torna dura y quebradizo con el martillado. Para recobrar su ductilidad y poder continuar con el proceso, efectuaba el "recocido" o calentamiento de la lámina al rojo vivo.

3. Sumergía la lámina en agua para enfriarla y la martillaba de nuevo.

4. Cuando hacía un casco, martillaba la lámina alternadamente sobre una horma cóncava de madera y otra convexa hasta conseguir la forma semiesférica del adorno. Periódicamente efectuaba el "recocido".
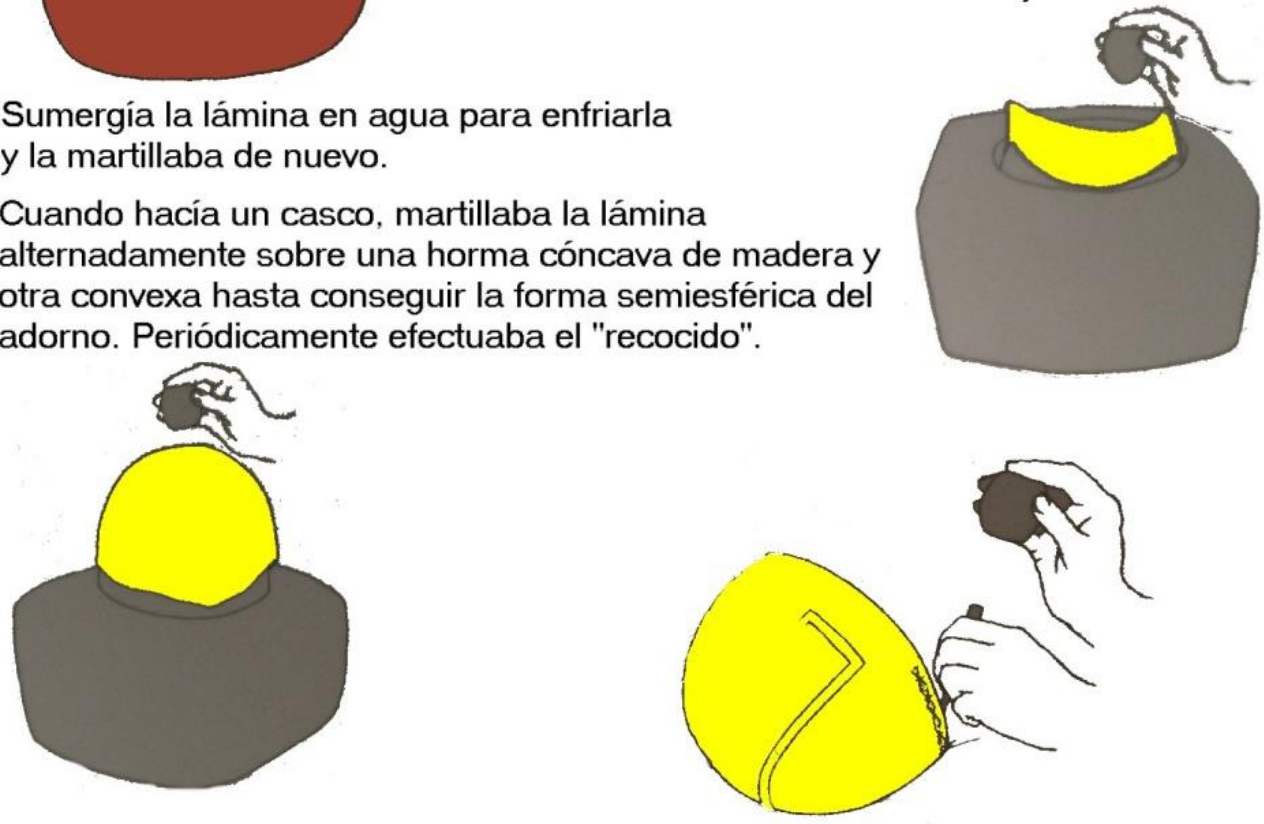

5. La decoración repujada la realizaba con la pieza apoyada sobre una superficie blanda como resina, brea o una bolsa rellena de arena. Dibujaba el diseño y luego lo repujaba usando diferentes tipos de herramientas. Alternaba el trabajo sobre las caras interna y externa.

Figura 25.

Fabricación de piezas martilladas. 

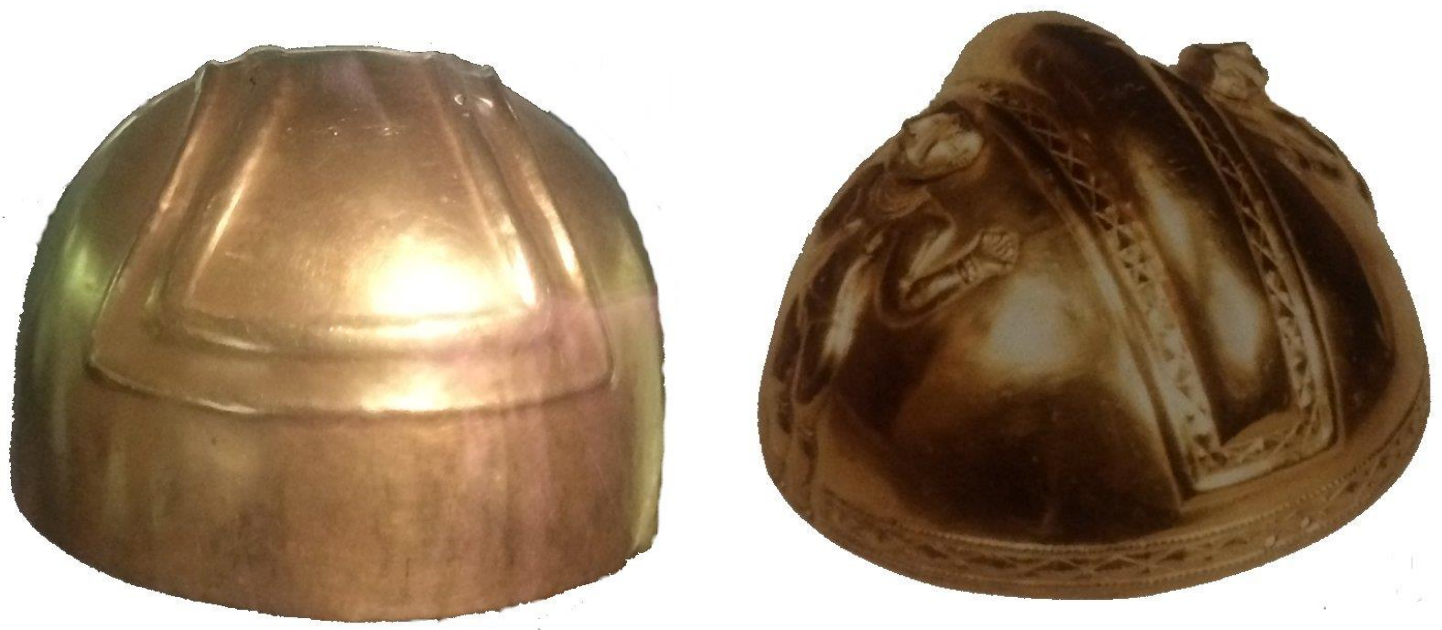

Figura 26.

Cascos elaborados por martillado y repujado. Las cabezas del último casco fueron fundidas y luego ensambladas en la pieza, encontrada en una tumba en Quimbaya, Quindío y pertenece a la Colección Museo de América, Madrid.

\section{El trabajo de los alfareros}

Los grupos agricultores del Cauca medio utilizaron la arcilla para hacer objetos destinados a diferentes usos en la vida cotidiana y ritual. Las piezas de cerámica de este museo reflejan un amplio conocimiento y dominio de la alfarería, así como una gran creatividad y sentido estético. Las formas y técnicas de los objetos sufrieron cambios con el tiempo y presentaron variaciones locales dentro de la región.

El alfarero comenzaba su labor con la extracción de la arcilla en la fuente de la materia prima. La amasaba para hacerla más homogénea y la limpiaba de impurezas. A veces le agregaba arena u otros materiales con el fin de darle mejor consistencia y evitar roturas en la cocción. Elaboraba la pieza por enrollado, modelado, con moldes o mediante una combinación de varias técnicas y la decoraba con incisiones, impresiones, pintura o adornos modelados. Con frecuencia pulía la superficie con piedras lisas. Una vez seca la pieza, la cocinaba en una fogata mientras mantenía control sobre el tiempo y la temperatura de cocción.

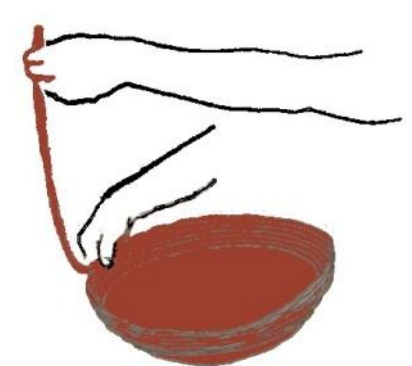

Técnica de enrollado molde

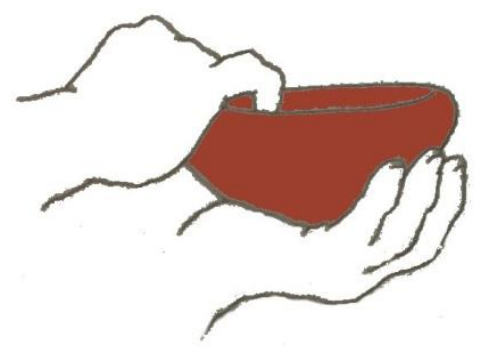

Técnica de Modelado

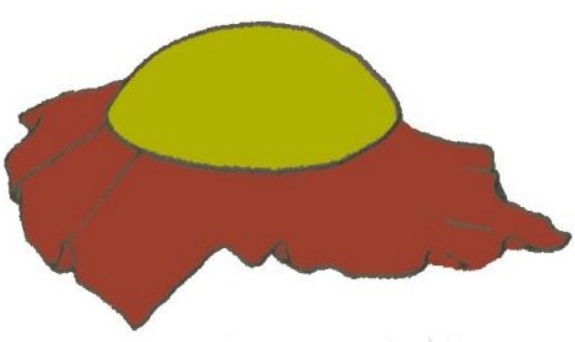

Técnica de fabricación con

Figura 27.

Técnicas usadas por los alfareros. 


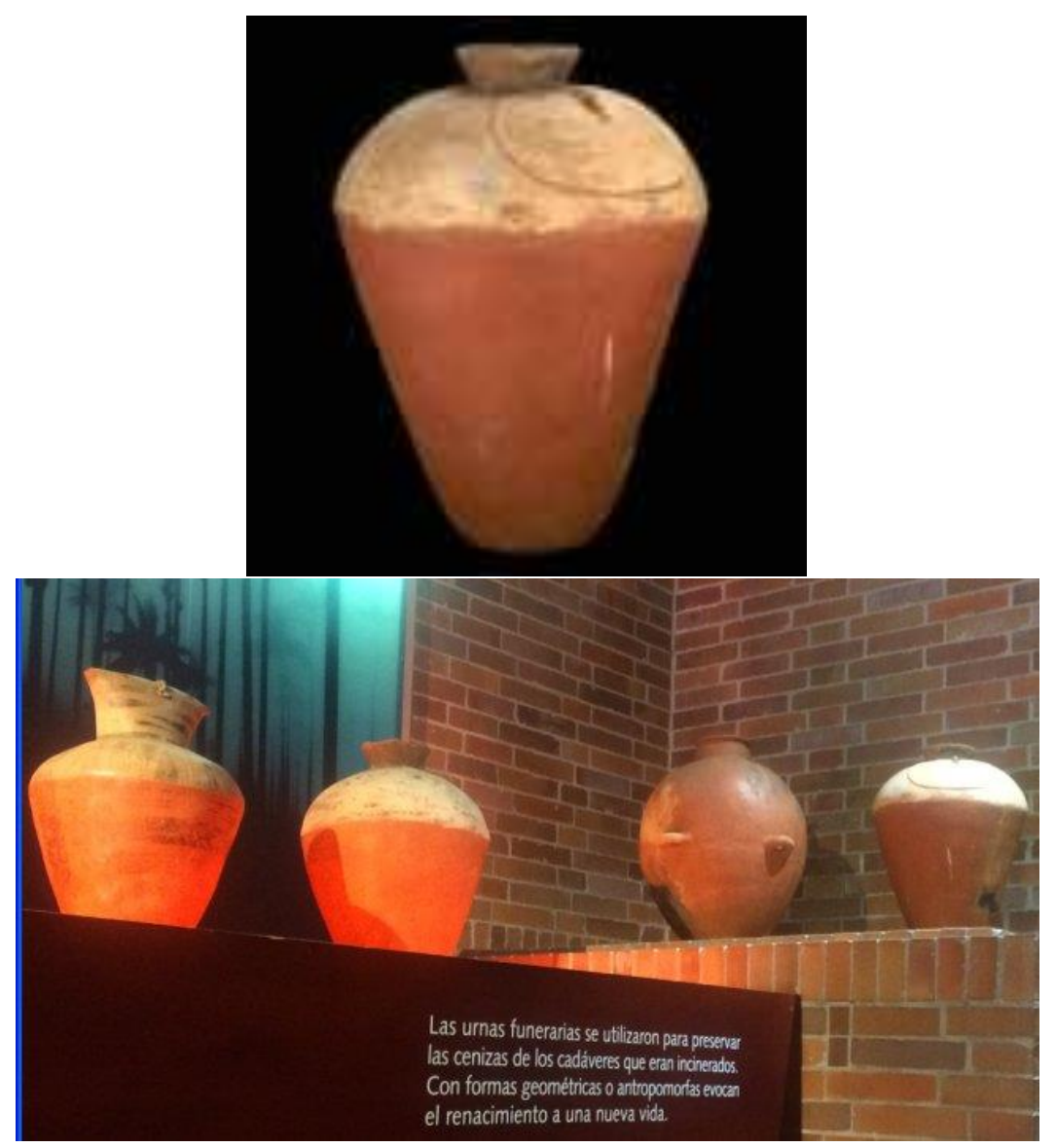

Figura 28.

Vasija para guardar cenizas humanas. Las urnas funerarias se utilizaron para preservar las cenizas de los cadáveres que eran incinerados. Las formas geométricas o antropomorfas evocan el renacimiento a una nueva vida.

\section{Arqueología}

\section{¿Y para qué cuidar el patrimonio arqueológico?}

El patrimonio arqueológico está integrado por los bienes muebles e inmuebles pertenecientes a culturas de períodos pasados, así como por los restos humanos y orgánicos relacionados con esas culturas. Este patrimonio es propiedad de toda la Nación y está protegido por la Constitución y las leyes.

El patrimonio arqueológico es un legado del pasado que nos permite conocer nuestros orígenes, construir identidad y reconocernos como grupo. La Arqueología trabaja para recuperar, conservar y divulgar este patrimonio.

\section{Una ciencia en busca de los orígenes}

La arqueología estudia la cultura material y las huellas de los grupos humanos del pasado con el fin de conocer sus formas de vida y pensamiento, y la manera como estas cambiaron en el tiempo. La cultura material la conforman los objetos, construcciones y demás manifestaciones tangibles elaborados por la gente para satisfacer sus necesidades individuales y colectivas.

Para conocer sobre las sociedades del pasado el arqueólogo investiga los objetos en su contexto; es decir, en su relación con los demás restos y huellas a su alrededor y con el lugar 
donde los encuentra, Esta relación le permite inferir sobre las actividades allí realizadas. En el Cauca medio la guaquería, o saqueo indiscriminado de las tumbas, ha extraído de su contexto un gran número de objetos del pasado y ocasionado así la pérdida de información valiosa sobre la vida y cultura de sus creadores.

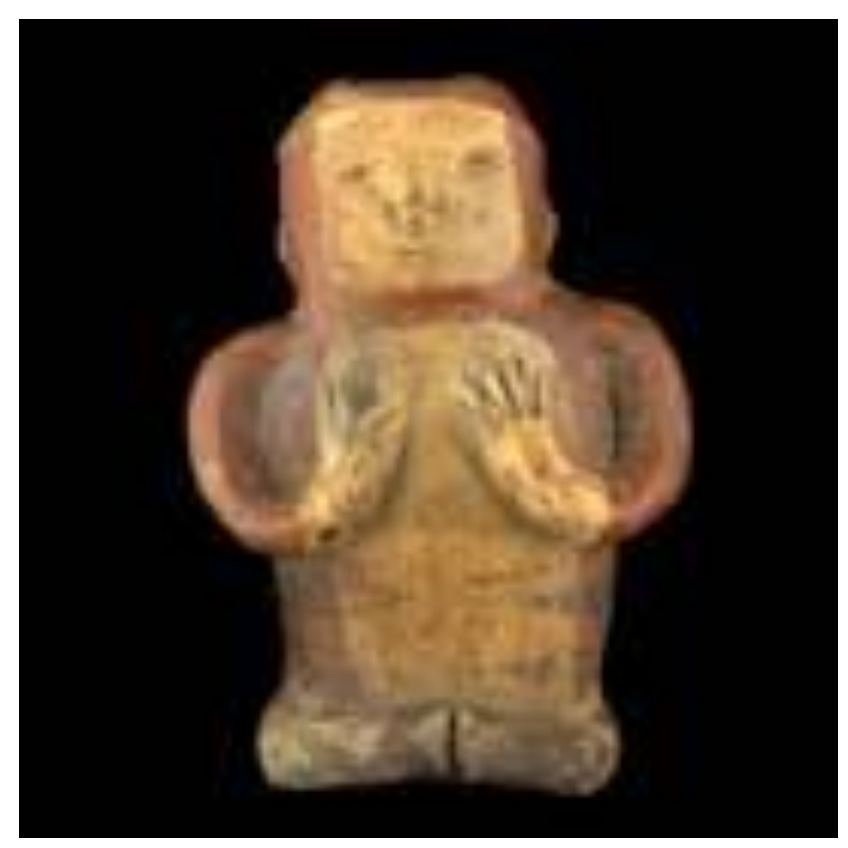

\section{El estudio de los metales antiguos}

La arqueometalurgia es una especialización de la arqueología que estudia los objetos metálicos del pasado con el propósito de conocer acerca de las materias primas y las técnicas utilizadas en su elaboración y sobre las actividades en las cuales fueron usados. En estas investigaciones se realizan análisis sofisticados con tecnologías complejas como el microscopio metalográfico que produce imágenes ampliadas de la estructura externa de las piezas.

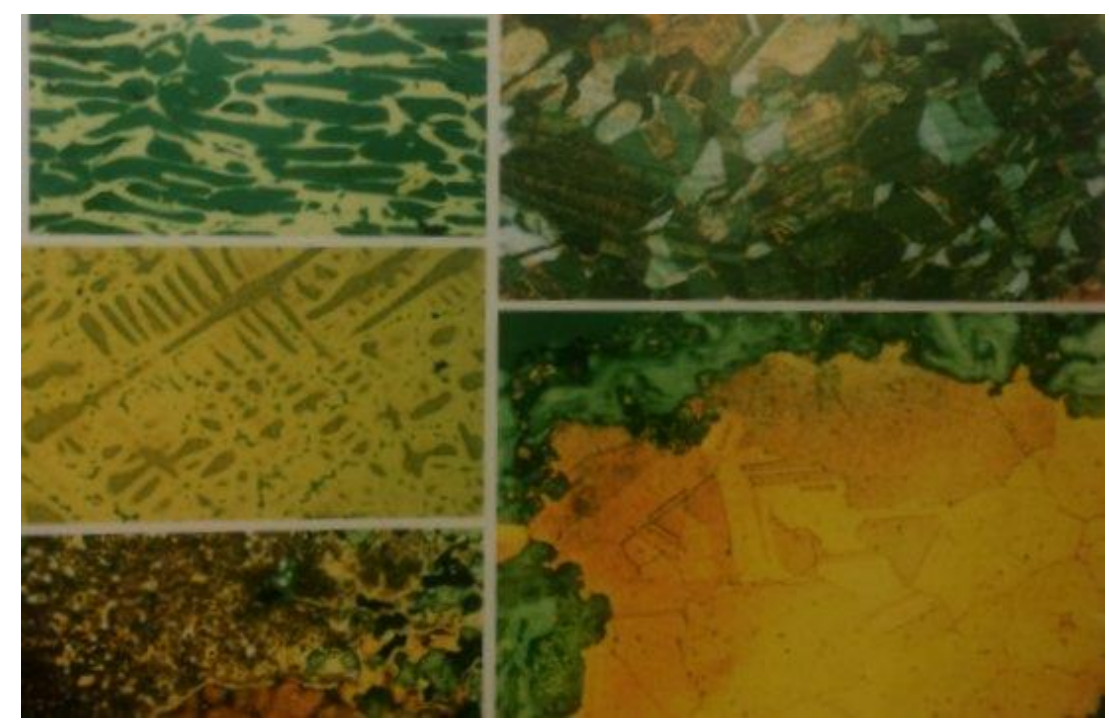

Figura 29. 
En el gráfico, metalografía o imágenes de la estructura interna de objetos de la colección del Museo del Oro obtenidas con el microscopio metalográfico.

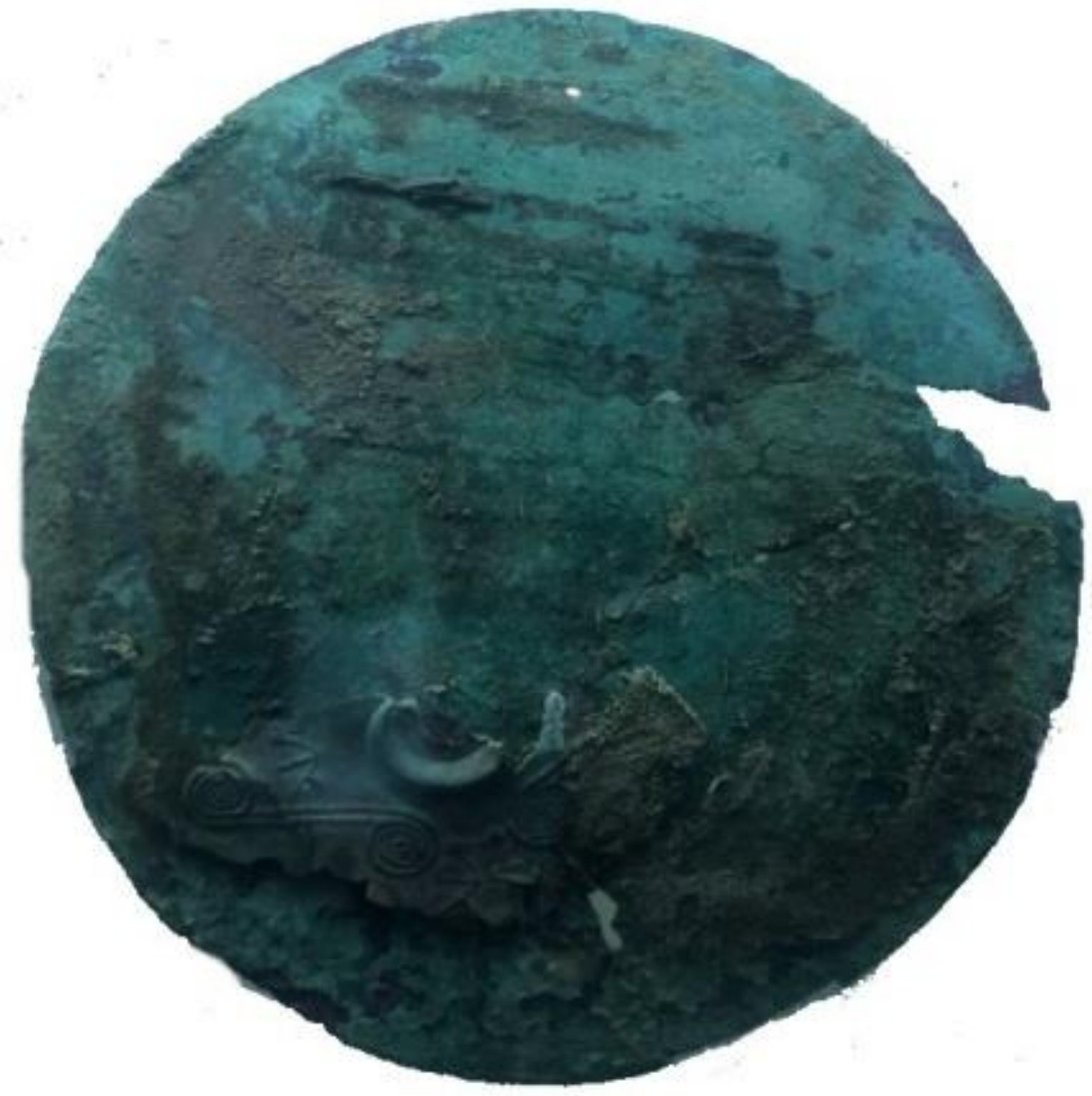

Figura 30.

Pectoral con nariguera y textil adheridos. El textil fue fechado por radiocarbono hacia el año 1000 después de Cristo.

\section{Los inicios de la arqueología en el Cauca medio}

Las primeras investigaciones arqueológicas en la región del Cauca medio fueron realizadas por el arqueólogo Luis Duque Gómez (1916-2000) entre 1941 y 1943. Duque y otros colegas fueron comisionados entonces por el Instituto Etnológico Nacional, hoy Instituto Colombiano de Antropología e Historia, para "buscar a los Quimbayas". Durante su misión estudiaron colecciones de objetos prehispánicos, recogieron datos sobre yacimientos arqueológicos y realizaron exploraciones y excavaciones en un sitio de vivienda en Supía, en cementerios de Riosucio, Armenia y Montenegro, y en basureros y otros rastros de pobladores antiguos en La Tebaida. 


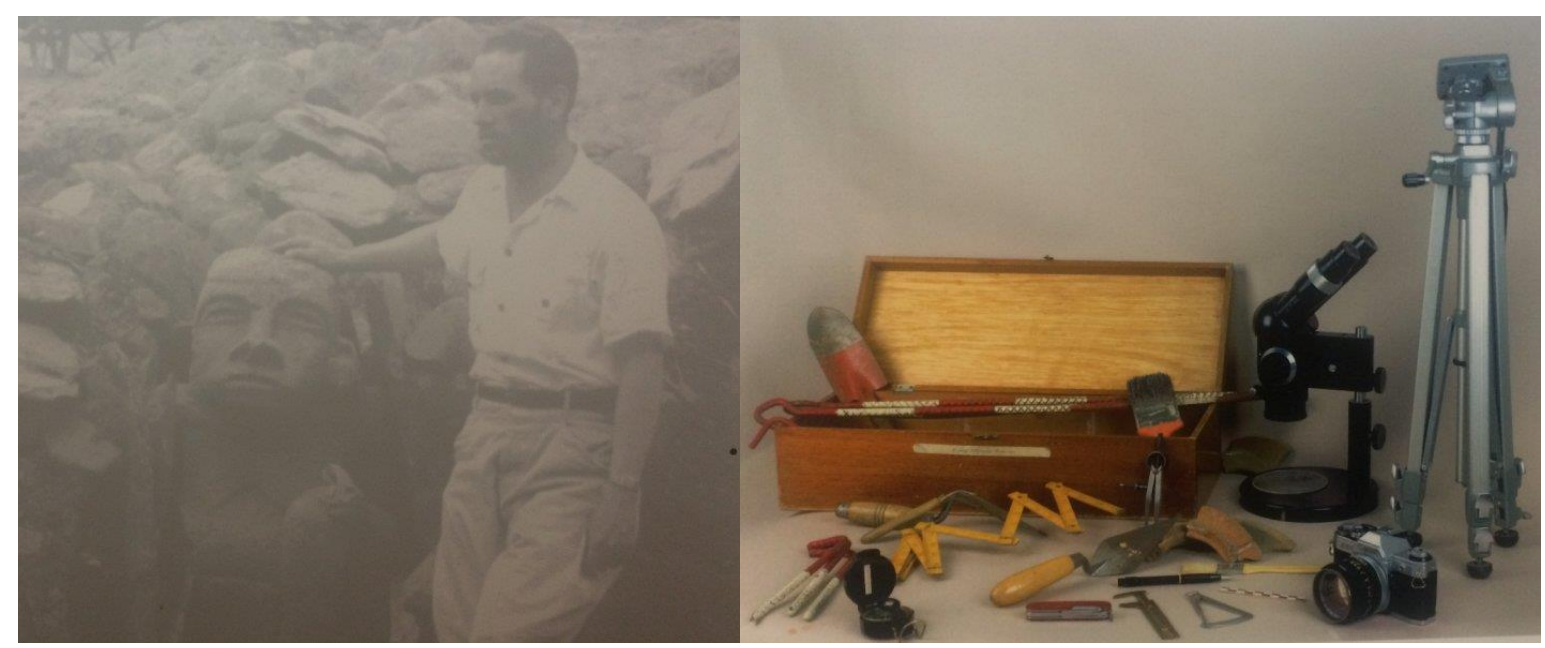

Figura 31.

En la foto de la izquierda, Luis Duque Gómez realizando excavaciones en San Agustín en 1946. Duque contribuyó con sus estudios al conocimiento del pasado prehispánico de Colombia, en especial de la región de San Agustín, y promovió la investigación científica desde la dirección de la Fundación de Investigaciones Arqueológicas del Banco de la República entre 1971 y 2000. En el trabajo de campo el arqueólogo utiliza palustres, palines, varillas, metro, brújula, brochas y cámara fotográfica, entre otras herramientas; en el laboratorio usa el microscopio, calibradores y cepillos y demás utensilios para el estudio de las evidencias arqueológicas.

\section{El trabajo del arqueólogo}

Muchos de los objetos o huellas del pasado se encuentran hoy en el subsuelo como resultado de la formación natural del suelo y de actividades humanas. Los arqueólogos excavan con minuciosidad y técnicas especiales que les permiten recuperar los objetos y la información sobre su contexto.

En el laboratorio, el arqueólogo limpia, marca, analiza y clasifica los objetos y demás evidencias que recuperó en la excavación. A partir del estudio de ellas y del contexto reconstruye las actividades realizadas en el sitio y aspectos de la vida en el pasado. El trabajo del arqueólogo está regido todo el tiempo por preguntas de investigación, métodos y teorías científicas.

\section{Relaciones culturales entre el suroccidente y el norte de Colombia}

Los arqueólogos tienen evidencias arqueológicas de que en el suroccidente de Colombia, entre el 500 a.C y el 1000 a.C., varias sociedades mantenían contactos, intercambiaban bienes de prestigio y compartían algunos símbolos. En el valle medio del rio Cauca son visibles las huellas de estos contactos. Cada una de estas sociedades creó sus propios y particulares estilos en el trabajo del oro, la cerámica y la piedra. A la vez estos estilos participaban de rasgos comunes de carácter regional.

Pectorales y cuentas de collar antropomorfas y antropozoomorfas esquematizadas de oro fueron producidas en todo el suroccidente y se encuentran con frecuencia en el valle medio del rio Cauca. Lo mismo ocurre con las alcarrazas con doble vertedera de cerámica.

Entre el 0 y el 1000 d.C. también se registraron contactos entre el centro y norte de Colombia y la baja Centroamérica. Con estos grupos, que habitaron los territorios de lo que hoy son Panamá y Costa Rica, se compartieron técnicas y estilos de metalurgia como la fundición, el 
uso de tumbaga, las representaciones de figuras humanas realistas, representaciones de animales de cola levantada y pectorales en espirales divergentes.

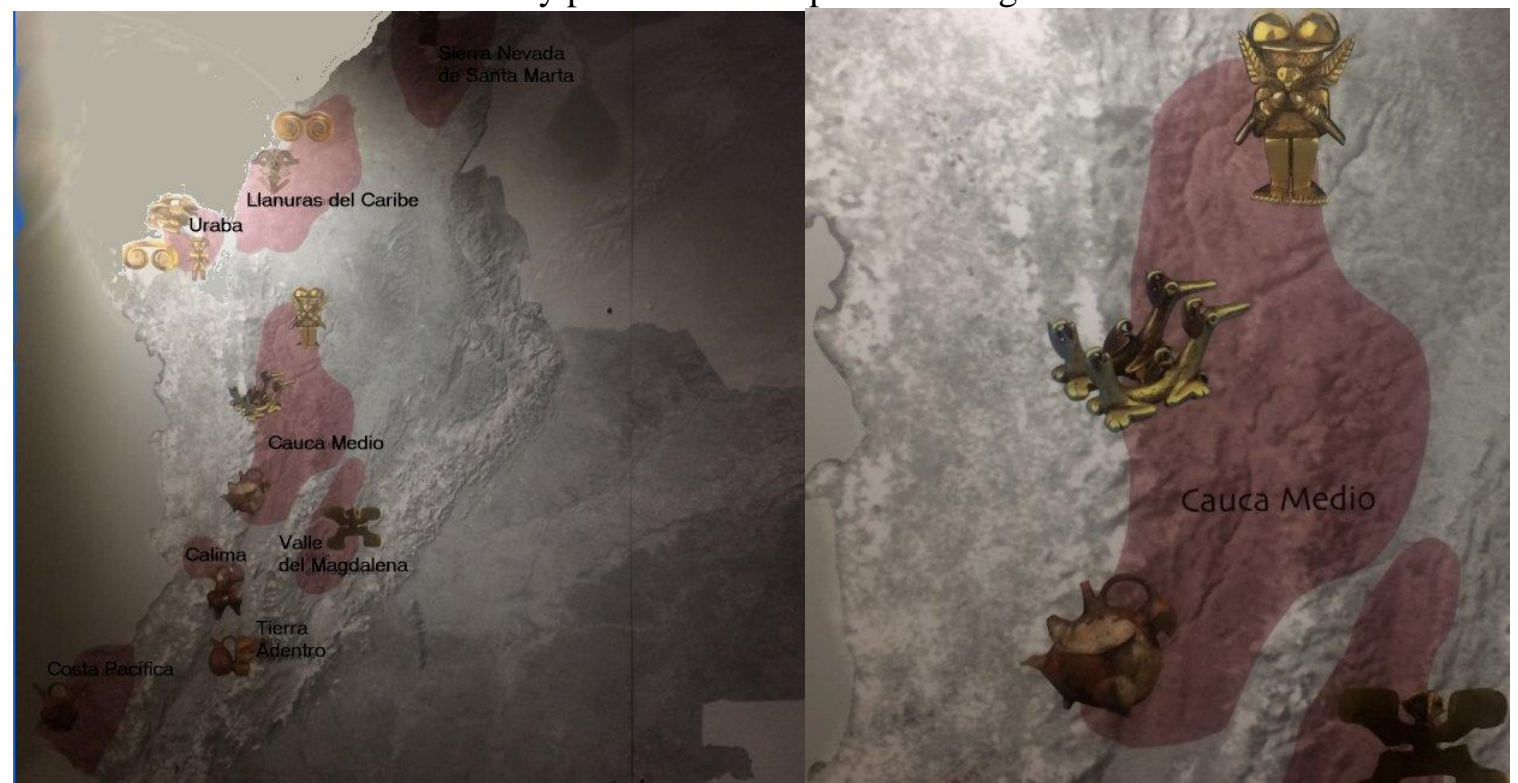

Figura 32.

Las sociedades que habitaban el valle medio del río Cauca mantuvieron relaciones estrechas con sus vecinos del norte y del sur. Se evidencian en rasgos comunes en la cerámica y la orfebrería. Los colgantes antropomorfos y algunos adornos como narigueras, similares a las quimbayas se encuentran en las orfebrerías zenú y tairona más antiguas.

\section{Hace 1.200 años...}

\section{Cambios culturales y un nuevo periodo de la historia regional}

Las evidencias arqueológicas indican que hacia el siglo IX d.C. la cultura material y algunas prácticas culturales de los pobladores del Cauca medio se transformaron. Estas transformaciones reflejan procesos de cambio en las sociedades que han llevado a los arqueólogos a definir un "Período Tardío" en la historia prehispánica regional.

La gran cantidad de sitios, tumbas y objetos de este periodo evidencia un incremento de la población y un desarrollo de la economía, mientras la enorme variedad en la cerámica y formas de enterramiento sugiere un proceso de diversificación cultural y diferenciación social.

Este periodo se prolonga hasta el siglo XVI, cuando los grupos de entonces sufrieron el impacto devastador de la Conquista española. Gracias a su fuerte resistencia, algunos de sus descendientes lograron sobrevivir hasta nuestros días.

\section{Los poblados y sus casas}

Los pobladores de este período, como sus antecesores, habitaron valles, laderas y cimas de montañas, cerca de fuentes de agua y recursos de fauna y flora. Prefirieron el piso térmico templado en donde el clima y la topografía son suaves y las tierras fértiles; allí modificaron el paisaje con la construcción de explanadas y obras agrícolas.

Ubicaron sus viviendas cercadas unas de otras formando aldeas, así como algunas dispersas. Los cultivos estaban cerca de las casas y a veces ocupaban grandes extensiones a lo largo de los valles. En el siglo XVI los conquistadores hallaron en algunas regiones casas pequeñas para una sola familia, y en otras, construcciones grandes donde habitaban varias familias emparentadas. Las viviendas de los jefes eran de mayor tamaño y tenían frente a su entrada un espacio abierto fortificado con una empalizada de guadua. 
Los pobladores de entonces encontraban en los guaduales materiales para construir sus acueductos, puentes, casas y fortificaciones. Con la guadua manufacturaron también armas y objetos de la vida cotidiana. Esta es una planta resistente, flexible, liviana y versátil que ha sido aprovechada por el hombre con enorme creatividad desde tiempos prehispánicos en la región.

\section{Las casas de los muertos}

Durante el Período Tardío los muertos fueron enterrados en cementerios o en sitios aislados ubicados en cimas de colinas, planicies naturales o áreas de vivienda. Las formas de las tumbas y de los entierros eran muy diversas y estaban tal vez relacionadas con el grupo social, clan familiar, rango o edad del muerto.

La mayoría de las tumbas eran de pozo y cámara lateral. Antes de rellenar el pozo, la entrada a la cámara era tapada con estacas de madera o lajas de piedra. El cadáver lo depositaban en la cámara a veces sobre esteras o troncos de madera, o con la cabeza y los pies apoyados sobre piedras. A su alrededor le colocaban ofrendas de comida, vasijas y otros objetos de cerámica, artefactos líticos y ocasionalmente adornos de metal. La tumba y estos objetos proveían al muerto de una casa y bienes para su existencia después de la muerte.

\section{Jorge Robledo en el entierro de un cacique}

Cuando morían, los jefes tenían el privilegio de ser objeto de un ritual funerario muy elaborado. El Conquistador Jorge Robledo presenció hacia el año de 1540, el entierro de un cacique de los alrededores de Anserma que su escribano consignó en un relato detallado:

"La manera que tienen en el enterrarse, cuando se muere algún señor, es en el campo, en parte escondida.... Primero le ponen entre dos fuegos en una barbacoa a manera de perilla a desainar [desangrar]... y después de muy seco, le envijan [pintan el cuero de rojo].... Y pónenle su chaquira en las piernas y brazos y todas las joyas que él estando vivo se ponía en sus fiestas, y envuélvenle en muchas mantas de algodón que para tal efecto tienen hechas y guardan mucho tiempo.... Y después le llevan a la sepultura que tienen hecha, y allí matan dos indios de los que a él le servían y pónenle uno a los pies y el otro a la cabeza. La sepultura es muy honda e dentro tiene hecha una gran bóveda que se cierra con unos palos que no se pudren... [allí] ponen sus armas e sillas en que se solía sentar y tazas con que solía beber e vasijas llenas de vino y platos llenos de los manjares que él solía comer, y dicen que lo hacen para que coma de noche, y así escuchan encima de la sepultura muchos días para ver si lo oirán”. Relación del viaje del Capitán Jorge Robledo a las provincias de Anserma y Quimbaya. Pedro Sarmiento, 1540. 


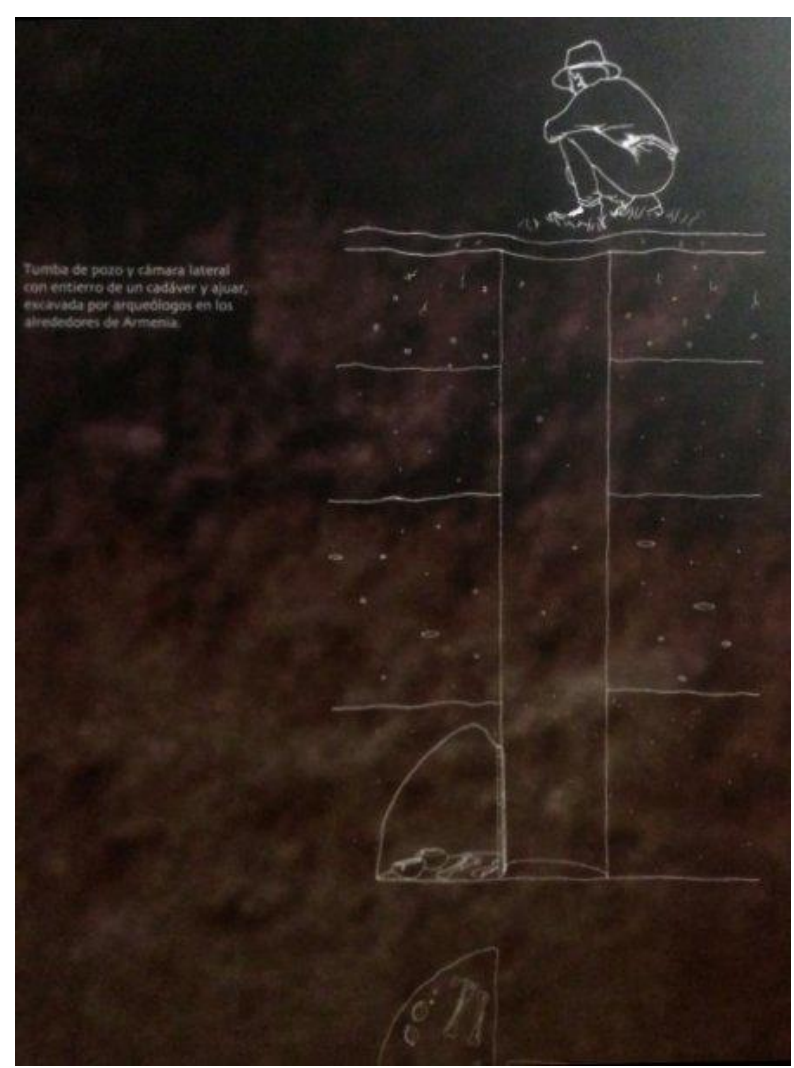

Figura 33.

\section{Guerra y canibalismo}

Estos grupos sostuvieron guerras por expansión territorial, competencia por recursos y disputas de poder. La guerra era a la vez un ritual al cual los guerreros iban cubiertos de adornos y pinturas y en el que tocaban trompetas y tambores. El canibalismo tenía un carácter ceremonial relacionado con la apropiación del espíritu o la dominación y venganza del enemigo. Algunos grupos, para infundir terror, exhibían cabezas-trofeo hincadas en cañas alrededor de la casa del cacique. La guerra y estas costumbres se intensificaron con la invasión europea.

\section{La vida cotidiana}

Tumba de pozo y cámara lateral

Los pobladores de este periodo practicaban diversas actividades. Cultivaban en los valles y las laderas, donde para evitar avalanchas de tierra y la erosión construyeron canales en sentido de pendiente y sembraron en eras perpendiculares a ésta. Del maíz, su principal cultivo, producían distintas variedades y en los climas templados y cálidos recolectaban dos cosechas cada año. [Pasado un tiempo], cambiaban de lugar sus sementeras para dejar recuperar el suelo.

[Cultivaron diversos productos en sus sementeras: frijol, maíz, calabazas, yuca, ají, batata. "Los relatos del siglo XVI cuentan que tenían "muchas arboledas de todas frutas": guayaba, piña, uchuva, aguacate, guamas, granadilla, pitahaya, guanábana, caimito].

Extrajeron sal de fuentes de agua salobre y oro de las arenas de los ríos. Fabricaron textiles de algodón y tejidos en otras fibras vegetales. Parte de la producción de estas industrias la dedicaron al intercambio con grupos vecinos y lejanos.

[En la cacería utilizaron diferentes tipos de armas, como el propulsor o tiradera, con el que arrojaban dardos]. 


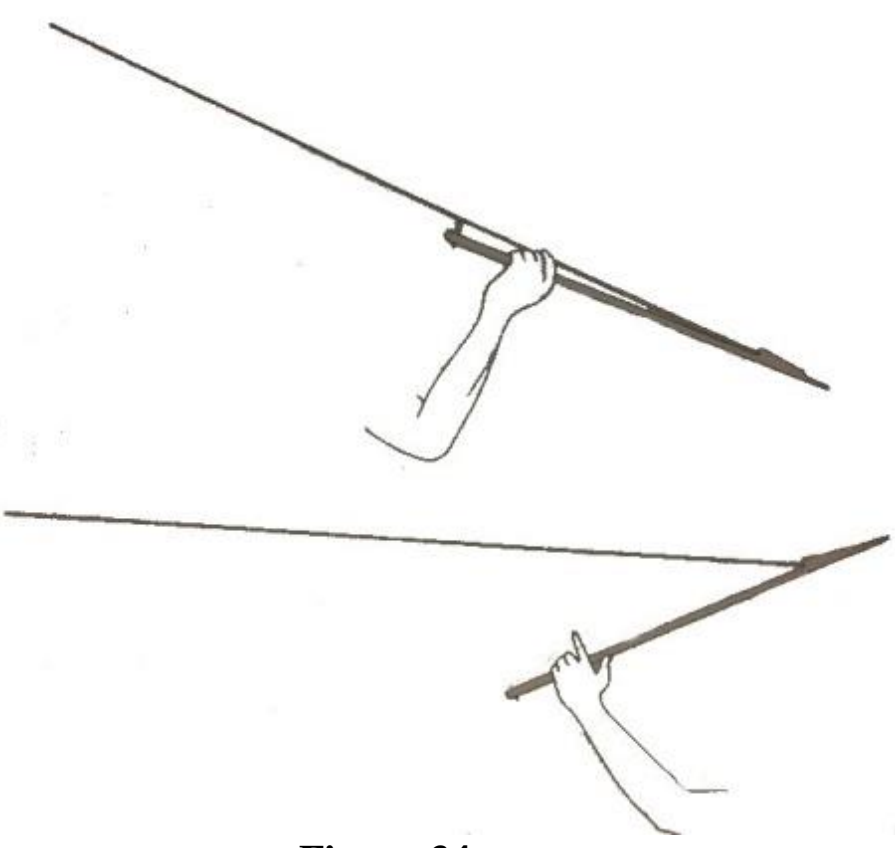

Figura 34.

También utilizaban hachas líticas para la agricultura.
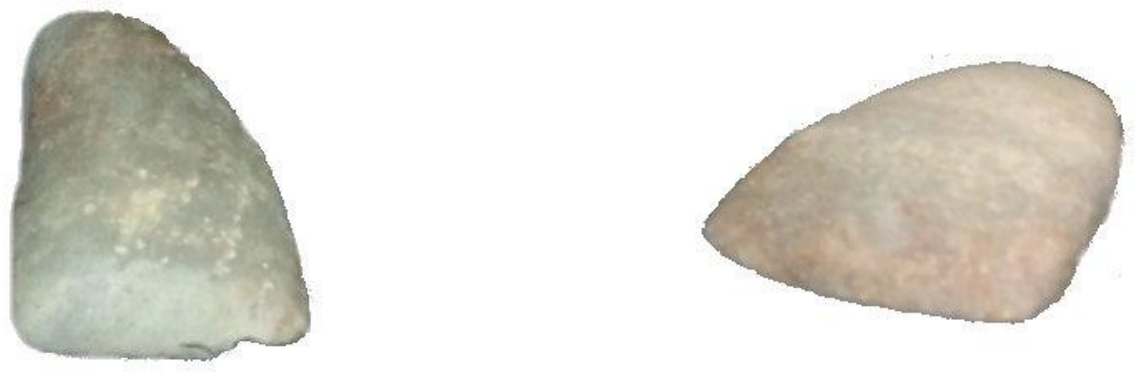

\section{Las piedras para moler el maíz}

"Las indias muelen el maíz en una piedra algo cóncava, con otra redonda que en las manos traen a fuerza de brazo. E así se hace una manera de pasta o masa, de la cual hacen un bollo y envuénvenlo en una hoja de la misma caña del maíz y otra semejante y asénlo y si no lo quieren cocer asan esos bollos en las brasas y tórnanse como pan blanco" Gonzalo Fernández de Oviedo y Valdés, en 1525.

Las arepas, bollos y demás preparaciones prehispánicas del maíz continúan siendo fundamentales en la cultura culinaria de la región y el país. 


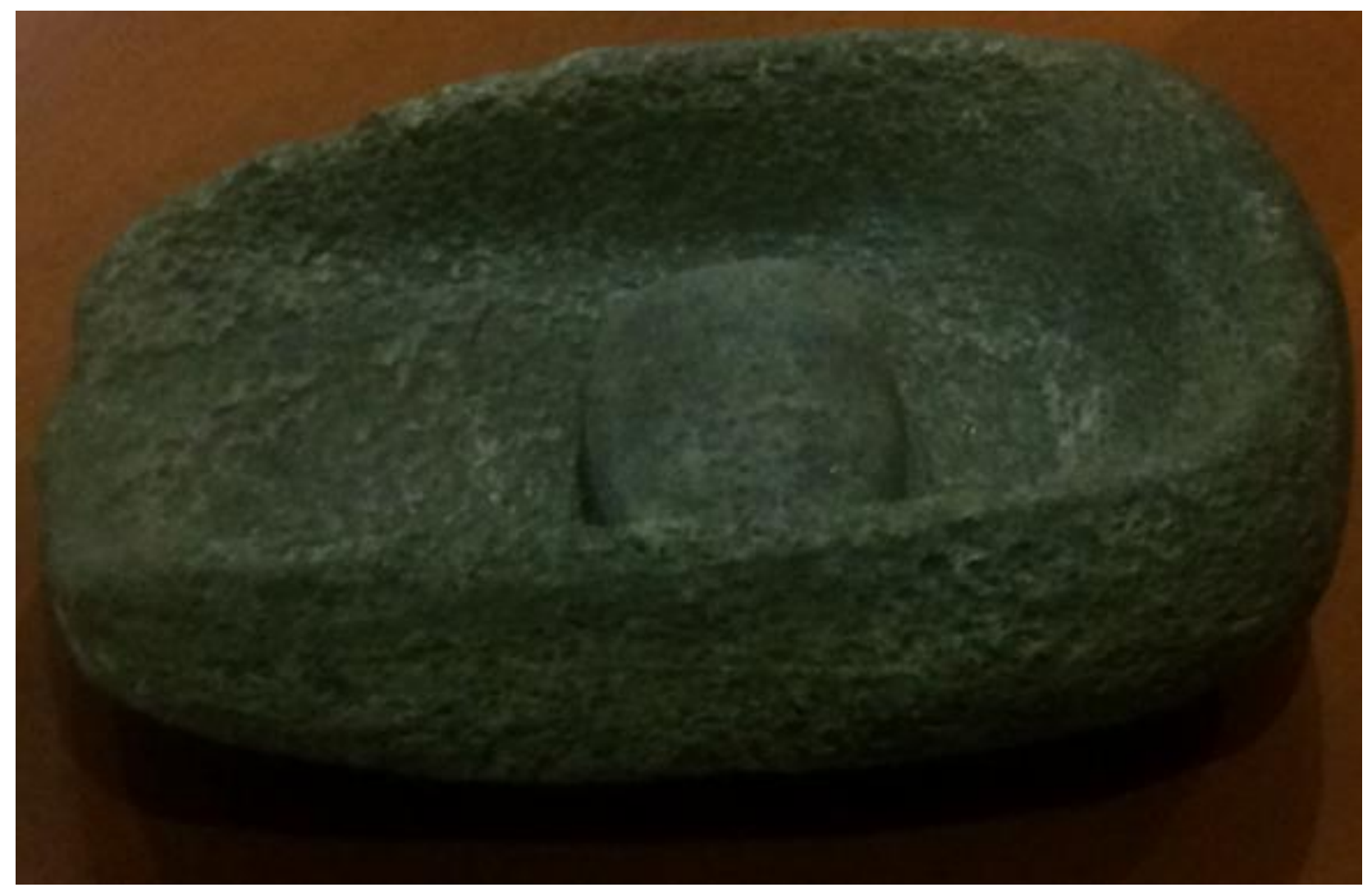

Figura 35.

Piedra de moler maíz.
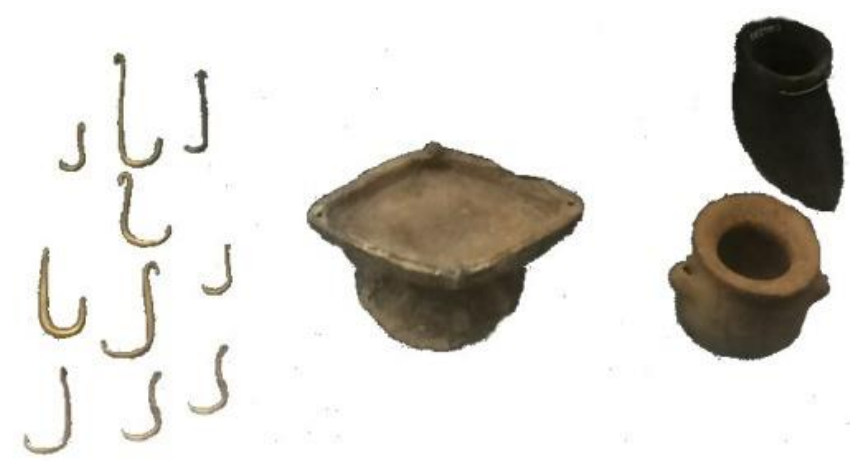

Figura 36.

Volantes de huso utilizados en el hilado del algodón y fibras

\section{La sociedad}

Estos grupos estaban organizados en cacicazgos, unidades políticas conformadas por varias comunidades lideradas cada una por un jefe que estaba bajo el mando de un cacique principal. Eran sociedades con diferencias de rango y producción económica de excedentes. Algunos individuos estaban especializados en determinados oficios.

Los jefes cumplieron funciones de liderazgo político, militar y religioso. Probablemente se encargaron de establecer alianzas entre comunidades, controlar intercambio, dirigir las obras comunitarias y mantener el orden social. En el siglo XVI los españoles los vieron conducir la guerra y presidir algunos rituales en sus casas. También vieron que eran respetados y 
temidos, y que tenían privilegios que los distinguían en andas o hamacas, vestían mantas de algodón pintadas, tenían varias esposas y usaba numerosos adornos de orfebrería.

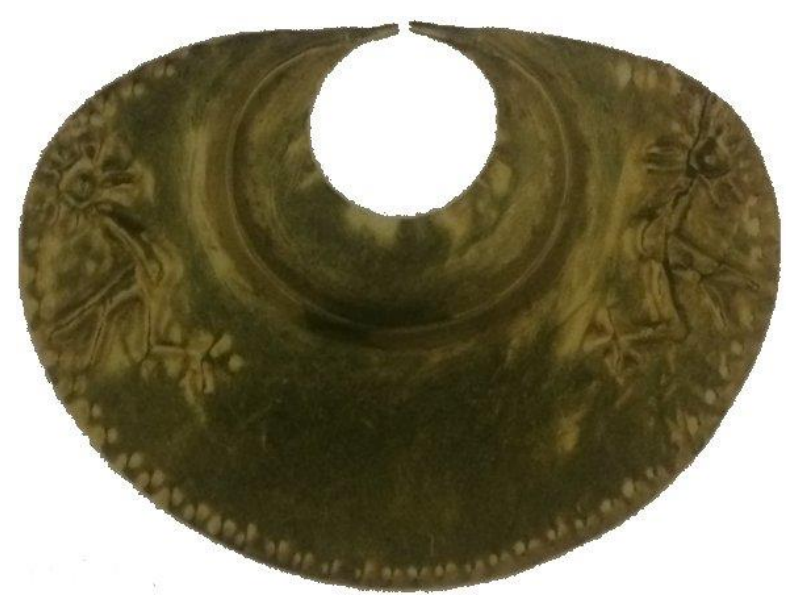

Figura 37.

Nariguera elaborada por martillado y repujado.

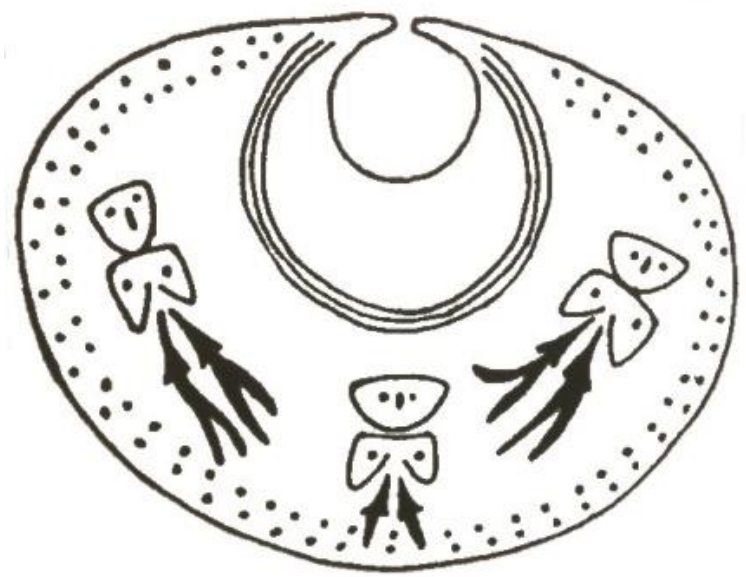

Figura 38.

Dibujo de nariguera con personajes estilizados. 


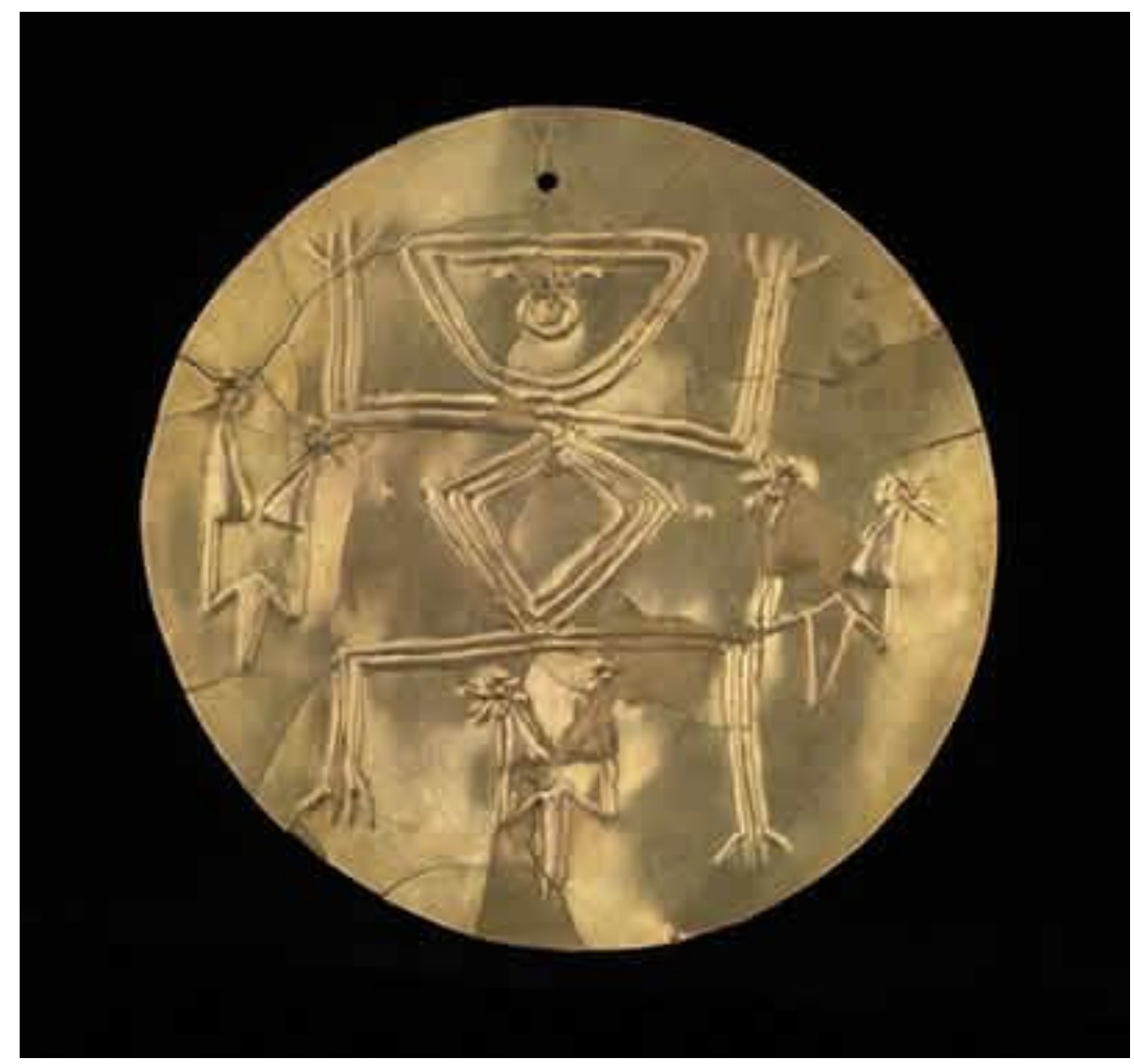

Figura 39.

Adornos de gran tamaño como pectorales circulares y narigueras triangulares, concedían prestigio a los caciques. Las figuras de hombre animal repujadas en los pectorales representaban el poder de transformación de estos dignatarios.

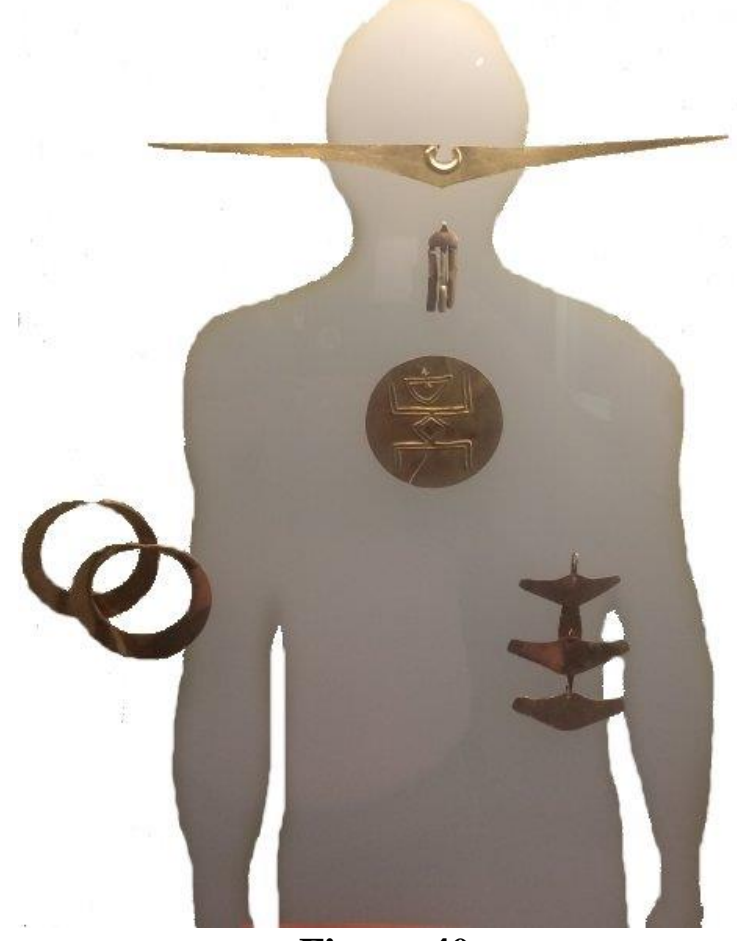

Figura 40 . 
Adornos de gran tamaño como pectorales circulares y narigueras triangulares, concedían prestigio a los caciques. Las figuras de hombre-animal repujadas en los pectorales representaban el poder de transformación de estos dignatarios.

\section{Hombres jaguar y hombres lagartija}

Entre diversas sociedades indígenas americanas existe la creencia de que el chamán, o especialista religioso, puede transformarse en ave y otro animal y así viajar al mundo sobrenatural. Los seres espirituales de ese mundo le informan la cura para las enfermedades, le enseñan cantos y le conceden animales de cacería.

En los pectorales, los orfebres del Período tardío repujaron figuras humanas y de hombre animal con rasgos de felino, reptil y batracio que probablemente representaban a los jefes como líderes políticos y como chamanes o dirigentes religiosos. Según los conquistadores españoles, algunos caciques del siglo XVI usaban un taparrabos largo como una cola, pinturas en la cara y el cuerpo, y uñas largas como garras, para trasformar su aspecto en el de un animal.
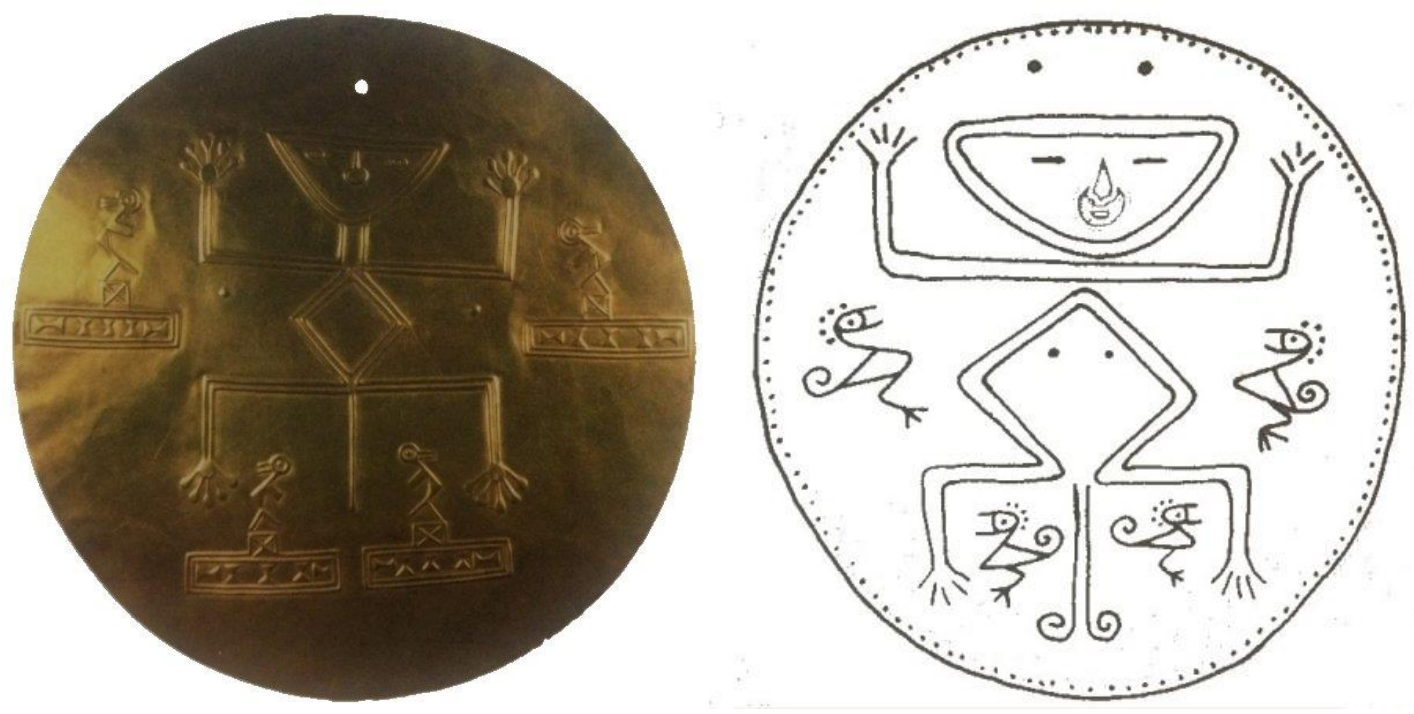

Figura 41.

Pectoral con figura de hombre lagarto. Colección Museo Etnográfico, Berlín. Las figuras repujadas en pectorales de orfebrería representan personajes, algunos humanos y otros en forma de hombre-animal. 


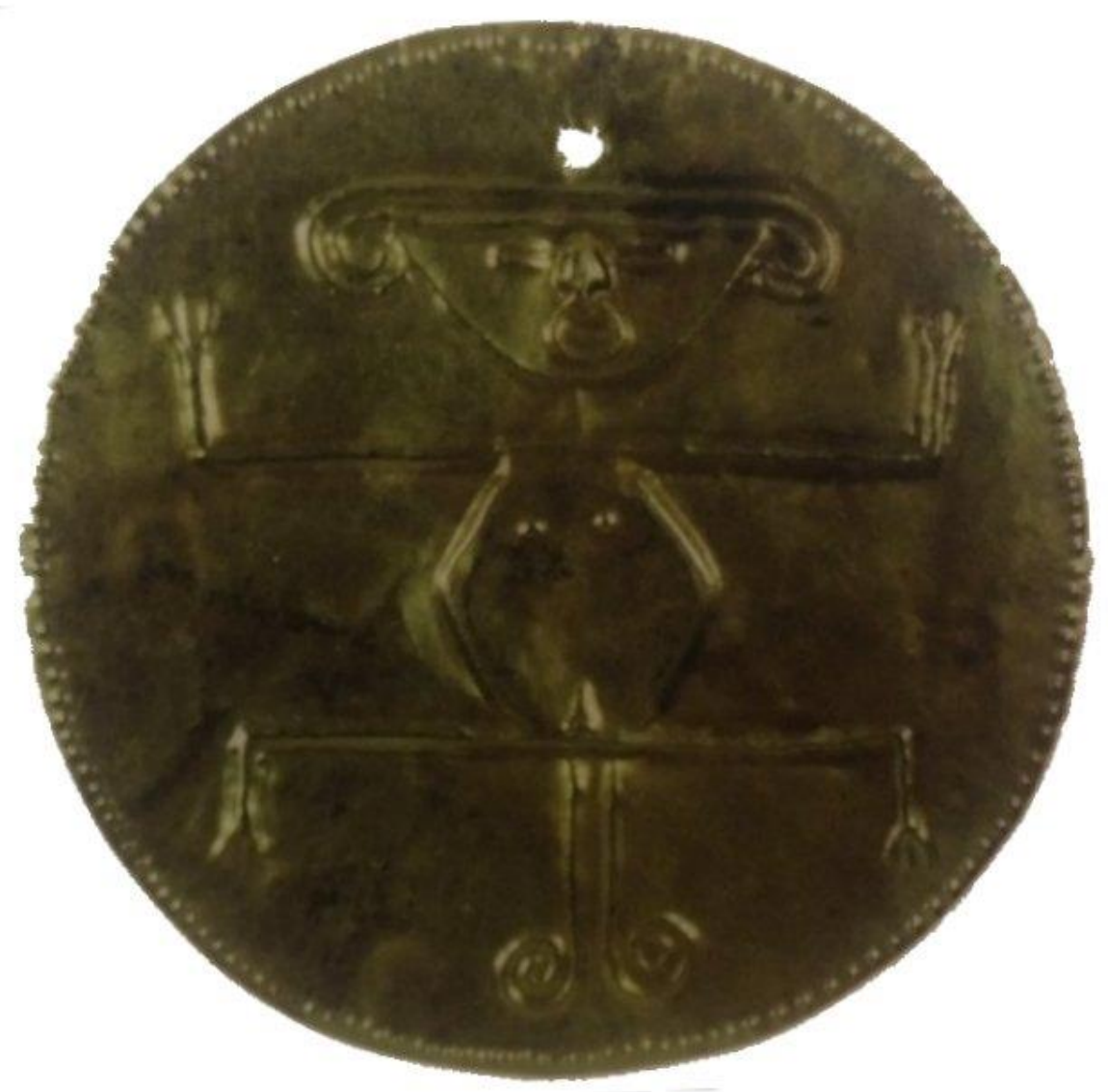

Figura 42.

Pectoral con representación de hombre-lagartija. Museo Británico, Londres.

En las figuras humanas de cerámica se observan las costumbres con las que transformaban su cuerpo, con ligaduras en brazos y piernas, pintura facial y corporal, y la deformación craneana y adornos (figura 43). De las semillas de la bija o achiote Bixia orellana, extrajeron un pigmento rojo para pintar. Con rodillos de cerámica imprimieron diseños de colores sobre la piel.

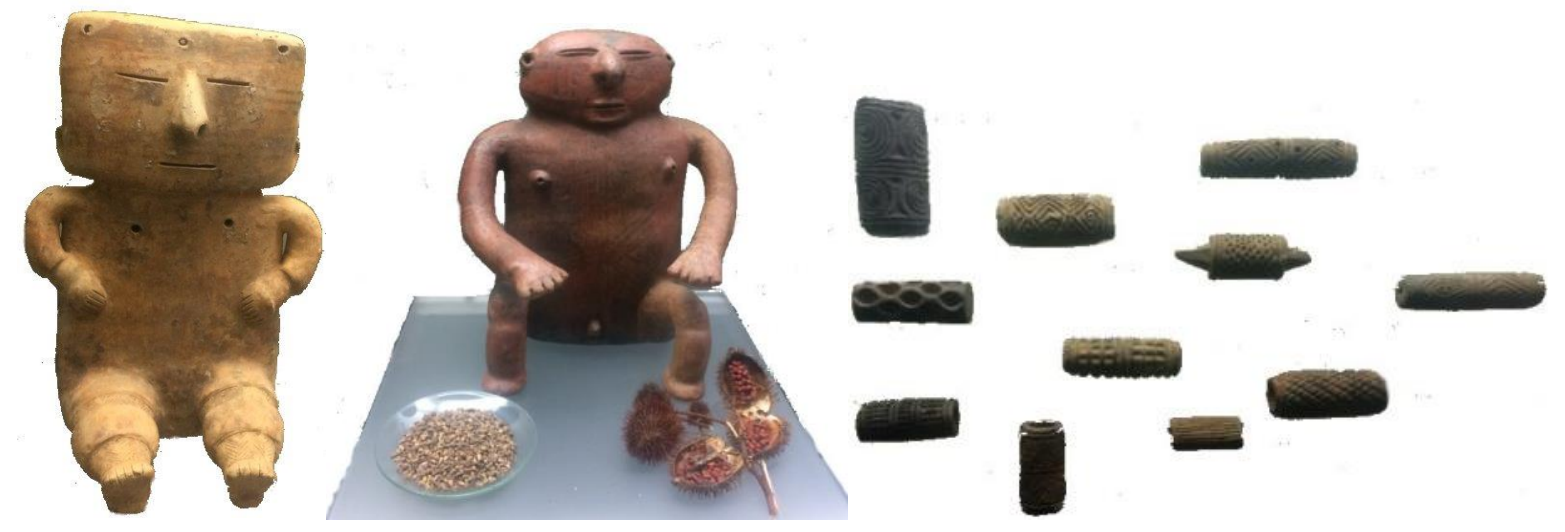

Figura 43. 
Figuras humanas de cerámica y rodillos de cerámica.

Las ligaduras con las que deformaban sus extremidades eran elaboradas con sartas de cuentas blancas. Cuentan las crónicas españolas que usaban coronas y otros adornos de plumas.

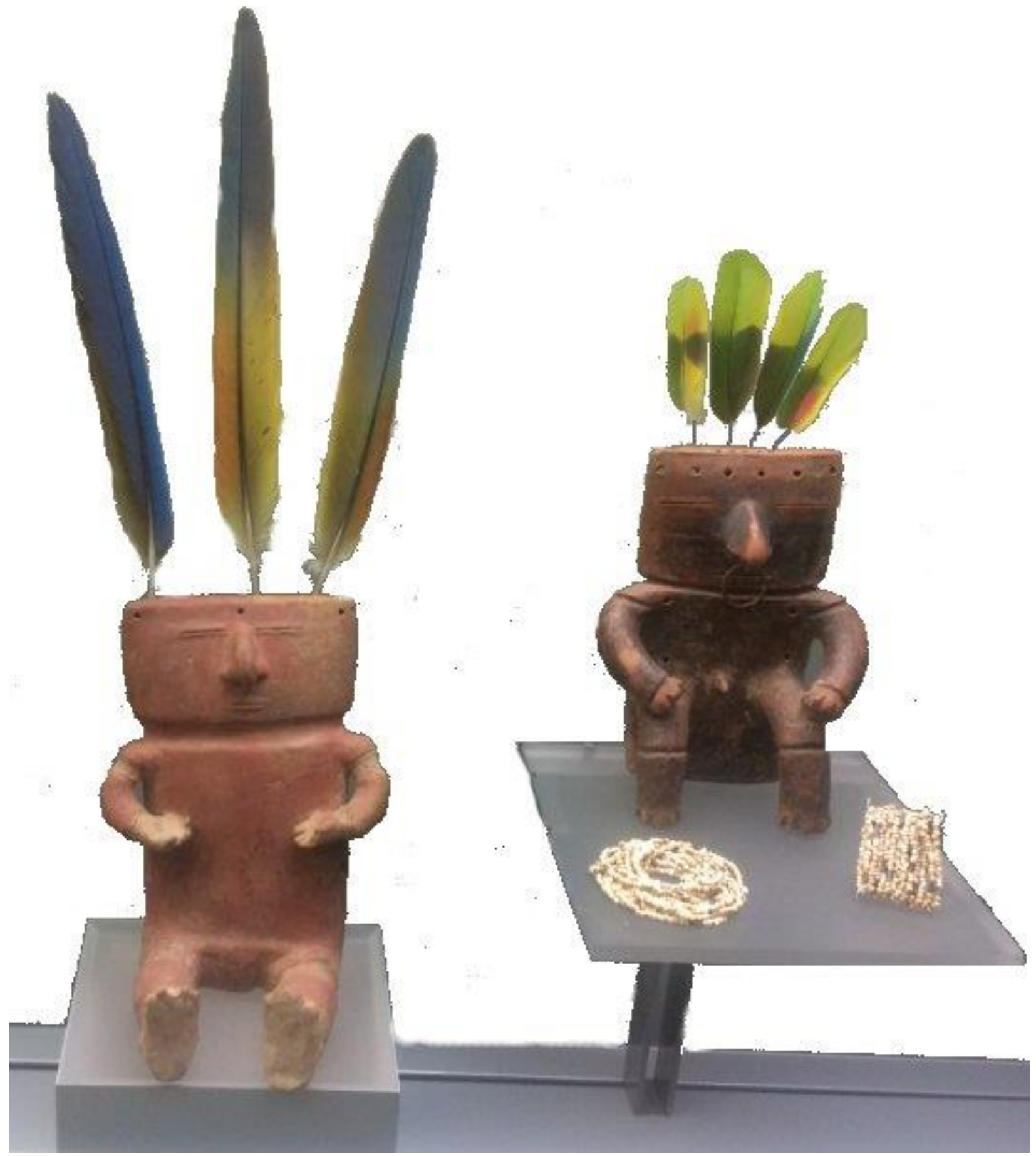

Figura 44.

Coronas y adornos de plumas. 


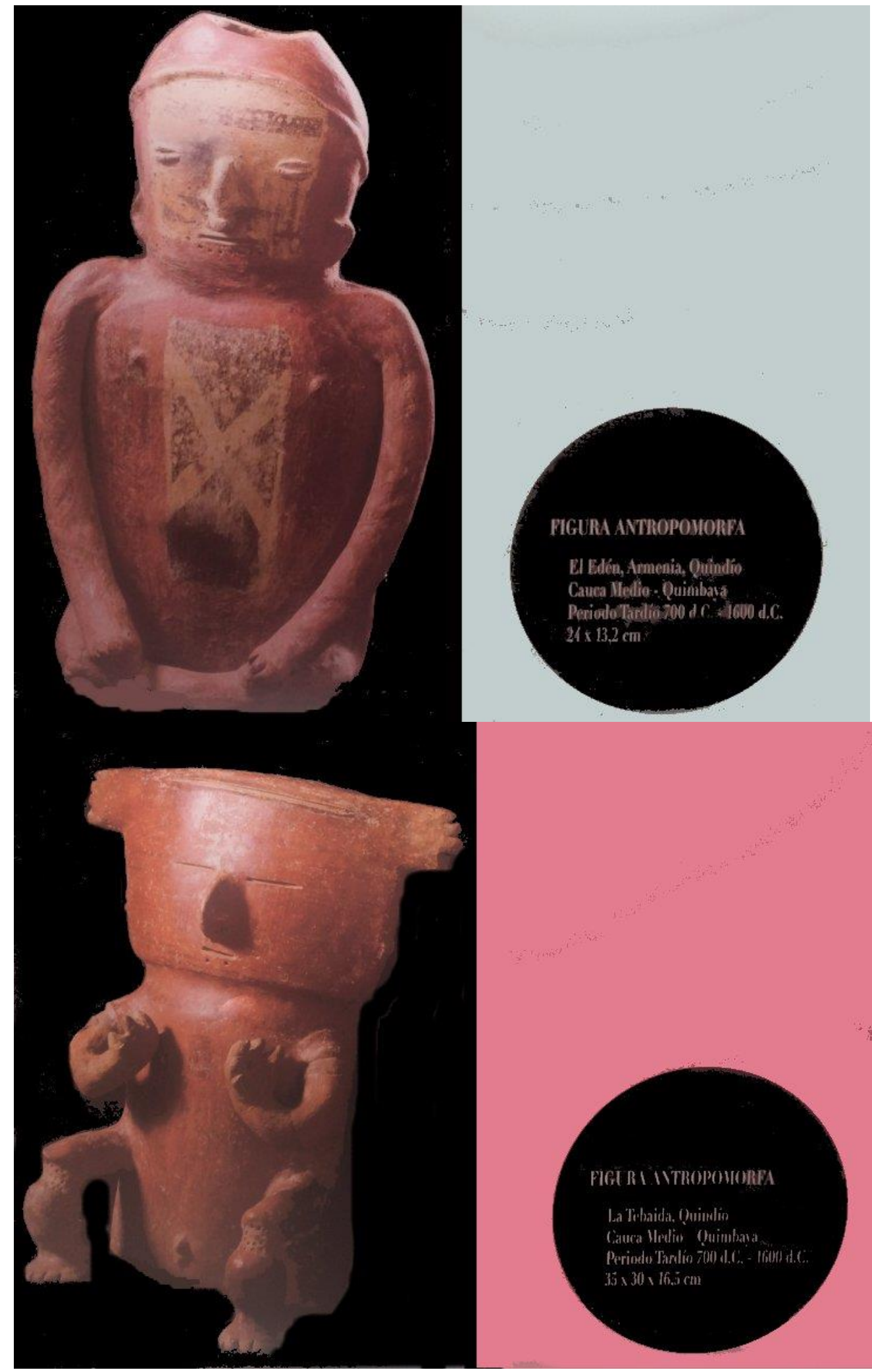

Hace 500 años...

¿Quiénes habitaban el cauca medio en el siglo XVI? 


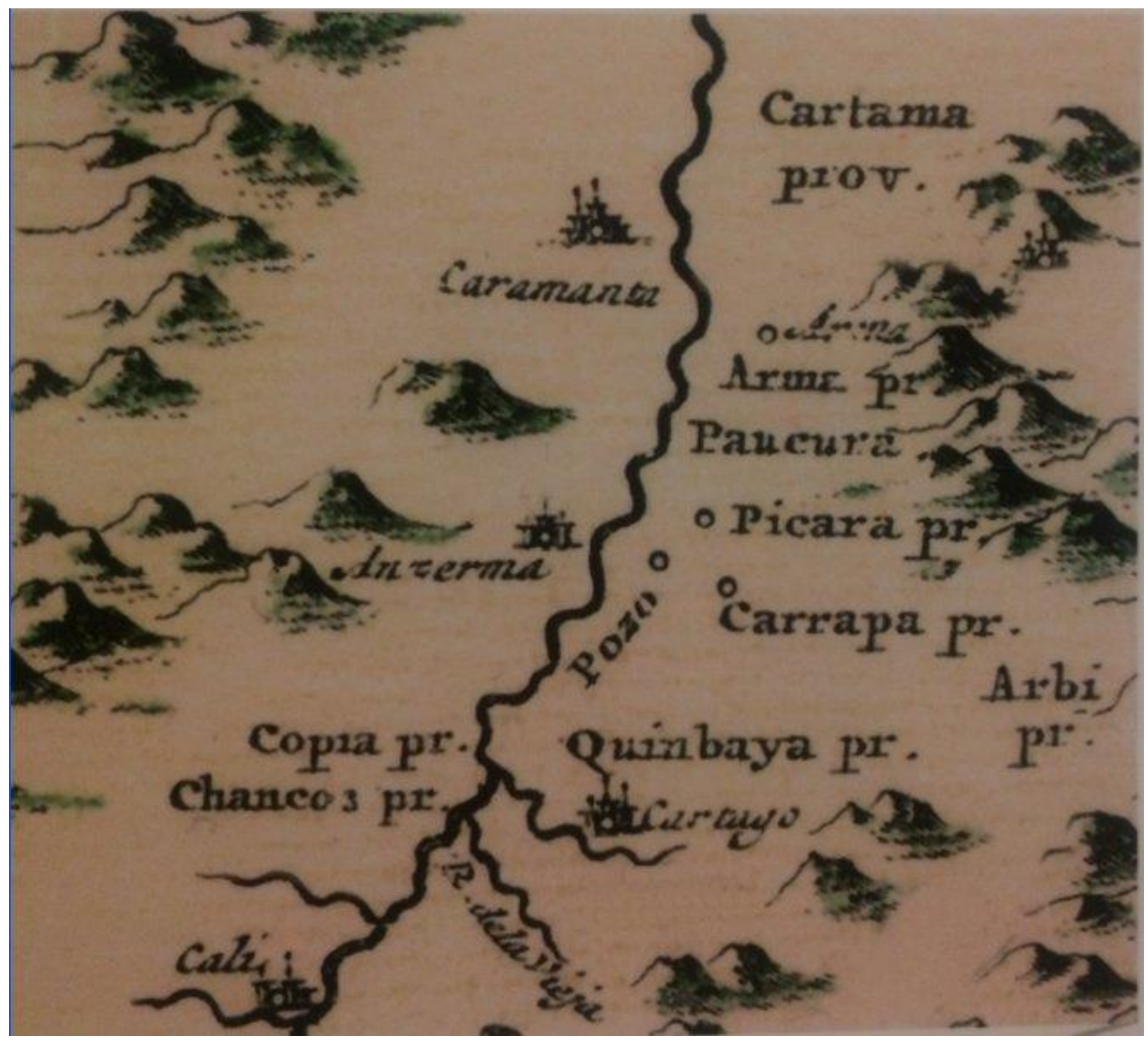

A su llegada a la región del Cauca medio hacia 1540. Los conquistadores españoles encontraron una población numerosa con diferencias locales en costumbres y lengua. De acuerdo con estas diferencias y su mirada europea, clasificaron a los grupos en "Provincias" que llamaron con nombres tomados de las lenguas nativas: Caramanta, Cartama, Zopía, Quinchía, Irra, Anserma, Chanco, Arma, Paucura, Pozo, Picara, Carrapa, Quinbaya y Quindo. Varios de estos nombres permanecen aún intactos o con pequeñas variaciones en la geografía de la región. 


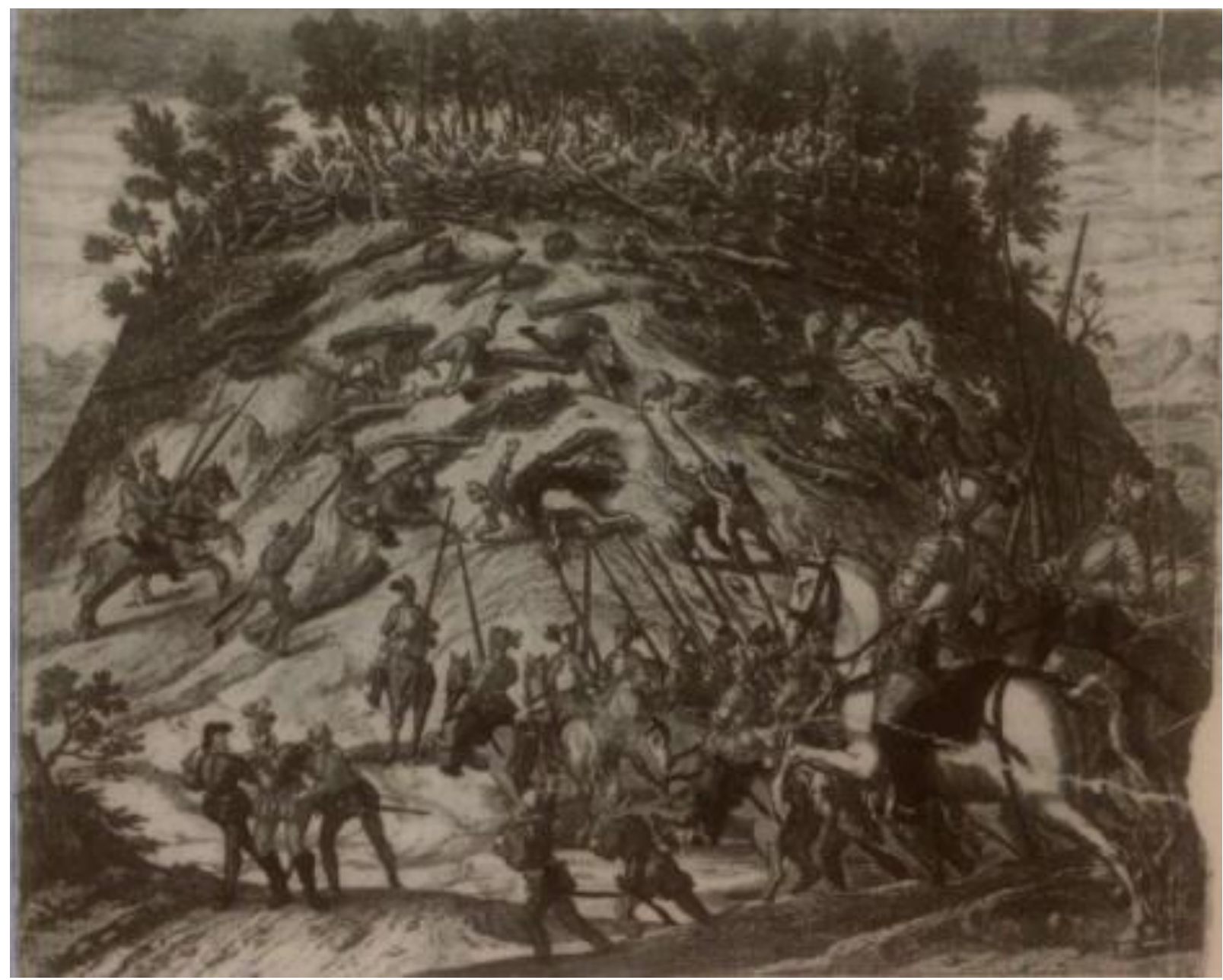

Figura 45.

Grabado de las guerras de Conquista. América, Theodor de Bry, 1592.

\section{La conquista española y lo que sucedió después}

La Conquista española condujo a la desaparición física y cultural de la mayoría de los grupos que habitaban el Cauca medio en el siglo XVI. Las guerras, enfermedades y maltratos diezmaron rápidamente la población, mientras el régimen de encomiendas, la evangelización y la reubicación de los "pueblos" desintegraron su organización y transformaron su cultura.

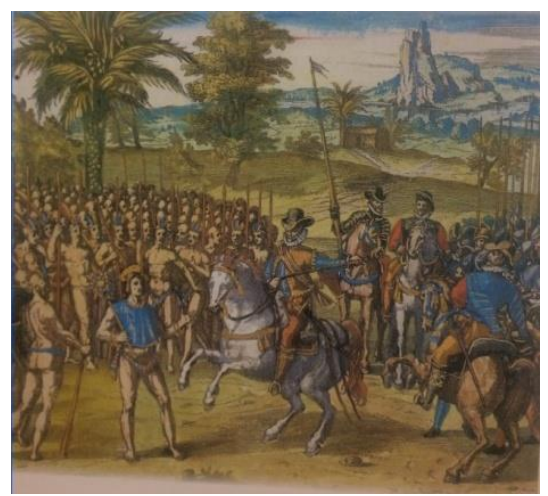


Pocos años después de la Conquista, los indígenas organizaron rebeliones para recuperar su autonomía y territorio, las cuales ocasionaron con frecuencia represalias contra los caciques y un trato más severo para la población. Los grupos sobrevivientes se replegaron a las montañas o huyeron hacia las selvas del occidente. Los colonos llegados de Antioquia a mediados del siglo XIX encontraron descendientes de estos grupos.

La colonización antioqueña, el auge del cultivo del café, el crecimiento de las ciudades y otros procesos recientes generaron mestizaje, nuevos desplazamientos y cambios en las poblaciones. Estos eventos, sumados a la historia milenaria anterior, constituyen los fundamentos de la sociedad actual y su cultura.

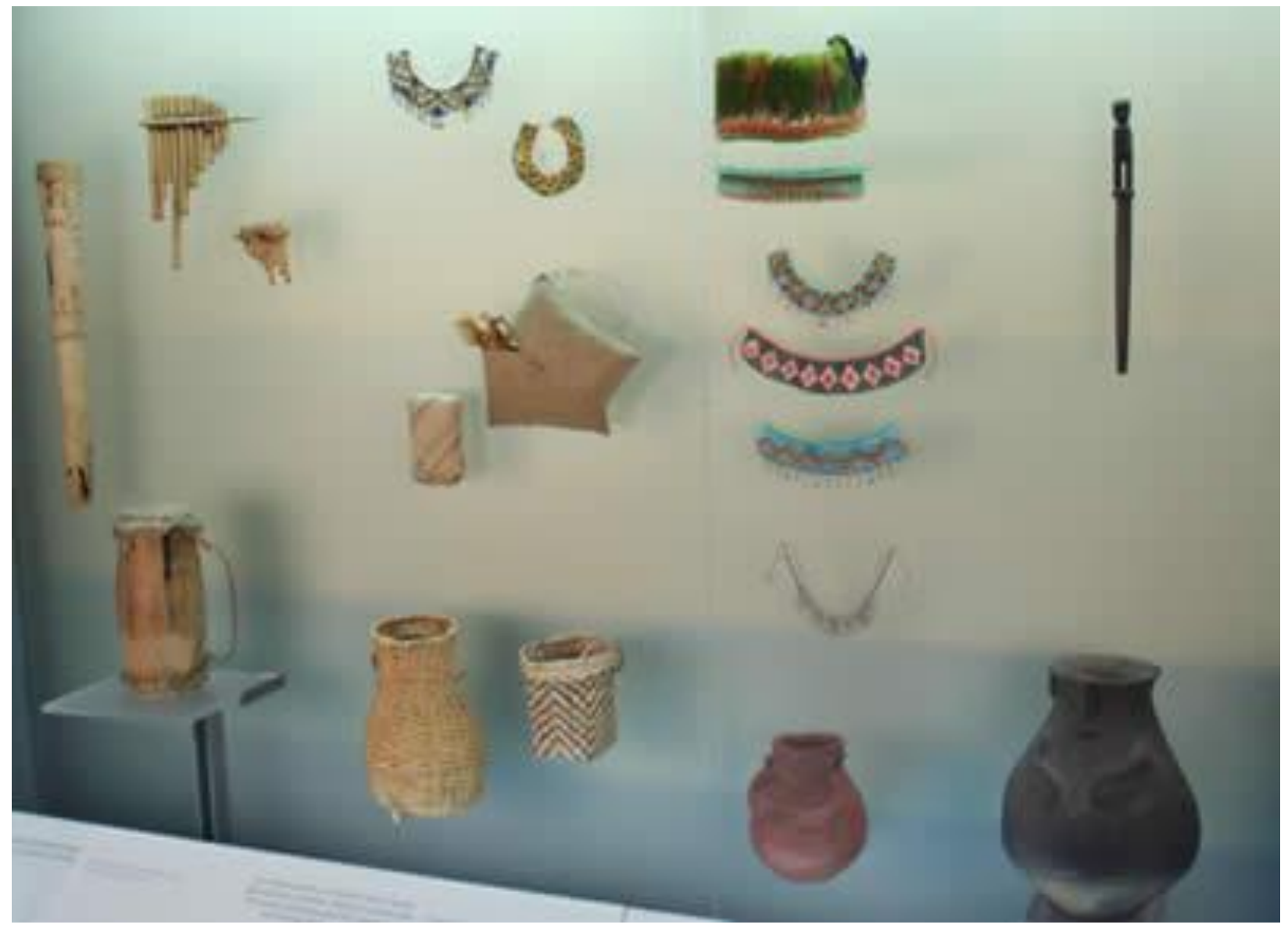

Hoy en día...

Los grupos indígenas actuales

Varias comunidades indígenas habitan el territorio del Cauca medio en la actualidad. Grupos Embera, llegados luego de la Conquista, se encuentran asentados sobre la Cordillera Occidental. Otras comunidades, probablemente descendientes de los pueblos encontrados por los españoles, habitan en los municipios de Riosucio y Supía, al occidente de Risaralda. Los Embera están organizados en comunidades que son lideradas por un cabildo y dueñas de las tierras donde habitan. Hasta hace poco su economía se basaba en la agricultura de maíz, la caza y la pesca, pero la disminución de tierras y de recursos ha menguado la importancia de estas actividades. Hoy cultivan principalmente plátano, trabajan como jornaleros y venden productos en las tiendas de los alrededores. El chamán de los Embera es conocido como jaibaná. Él establece contacto con los espíritus para averiguar las causas de las enfermedades y su tratamiento, atraer la pesca y animales de cacería, propiciar buenas cosechas y conocer 
el futuro. También preside ceremonias como la de inauguración de las viviendas, los entierros, la iniciación de los jóvenes y las fiestas de la cosecha.

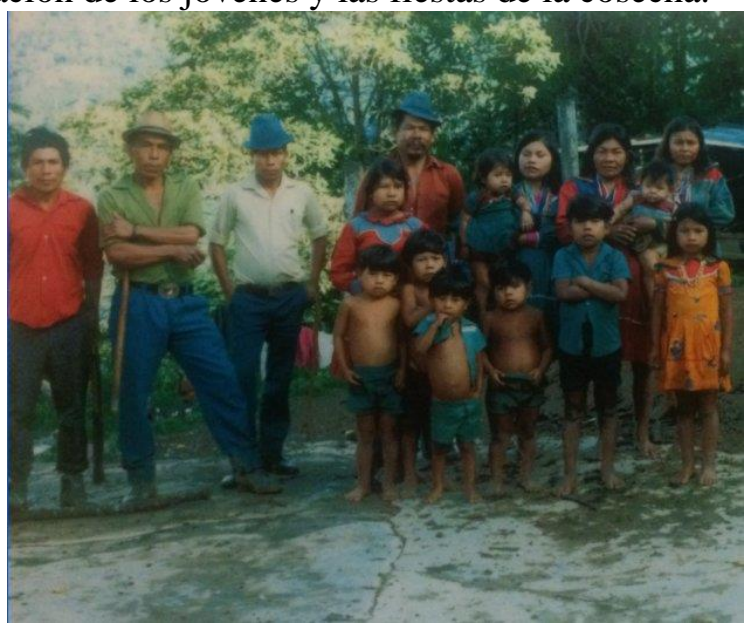

Figura 46.

Familia extensa en los alrededores del río San Juan, Risaralda. Los lazos de parentesco son fuertes entre los embera.

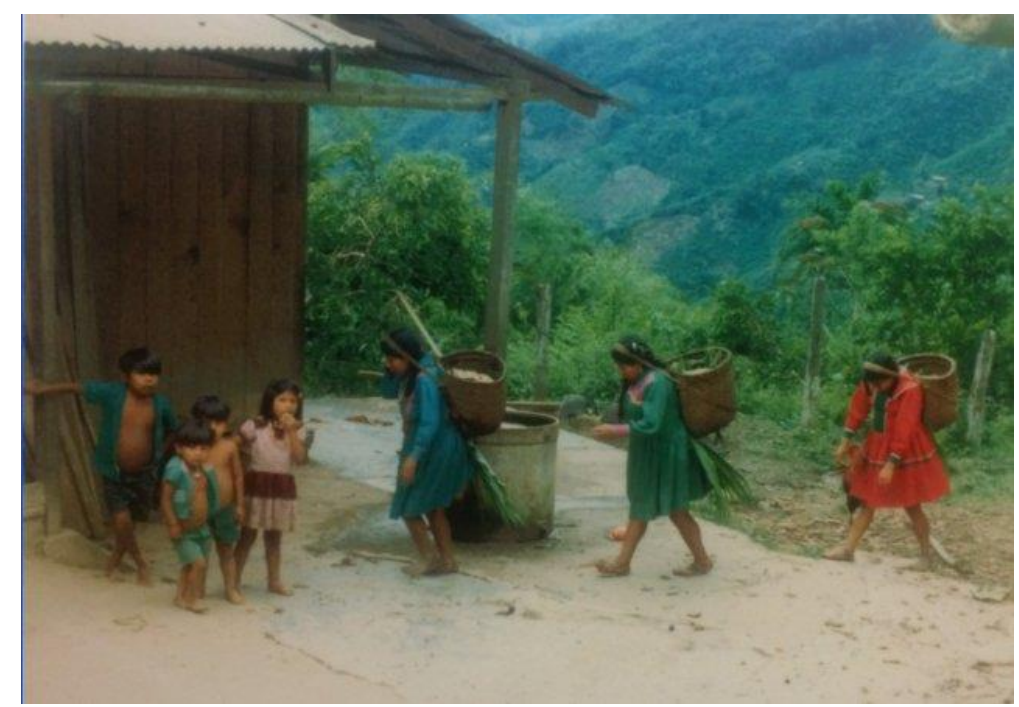

Figura 47.

Mujeres cargando cacao recién desgranado en grandes canastos elaborados por ellas mismas u otras mujeres de la casa.

Los embera conservan aún muchas de las tradiciones como la pintura facial. Los diseños de la pintura varían según el sexo, la edad, el clan y el estado anímico de la persona. También se usan para curar, proteger y propiciar estados positivos. 


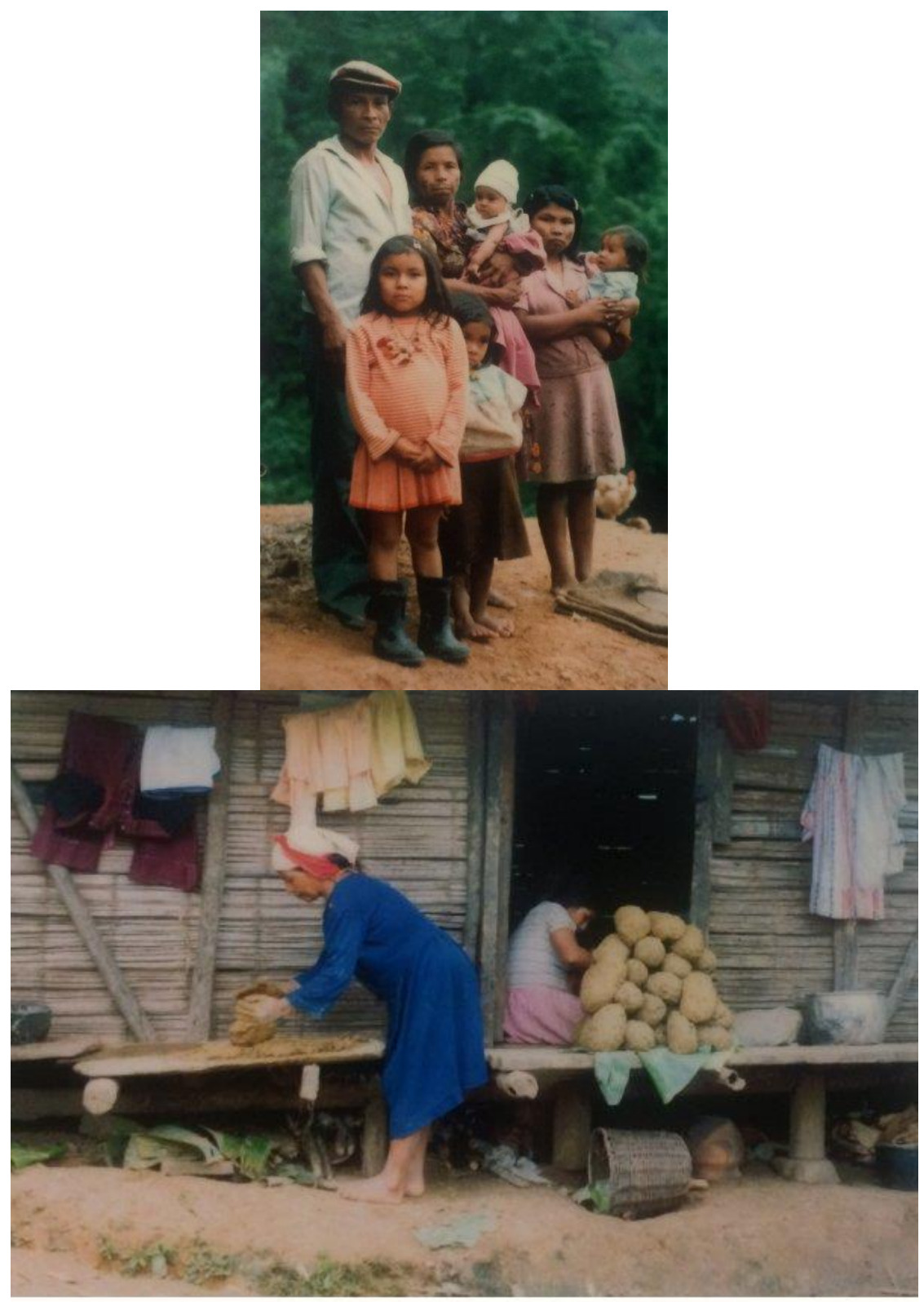

Alfarera preparando la arcilla para hacer cerámica

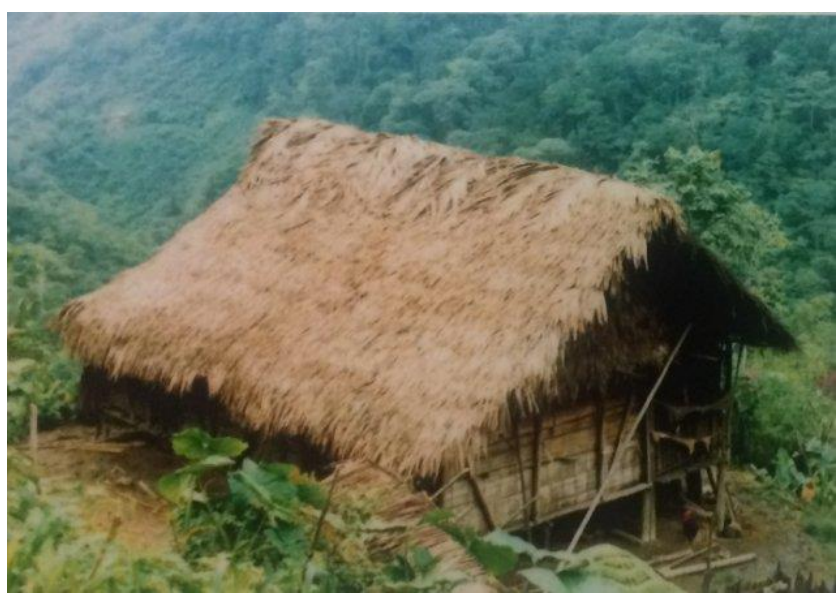




\section{Figura 48.}

Las casas emberas, elevadas sobre pilotes, son construidas con madera, guadua y palma. En ellas habita una familia nuclear o varias emparentadas.

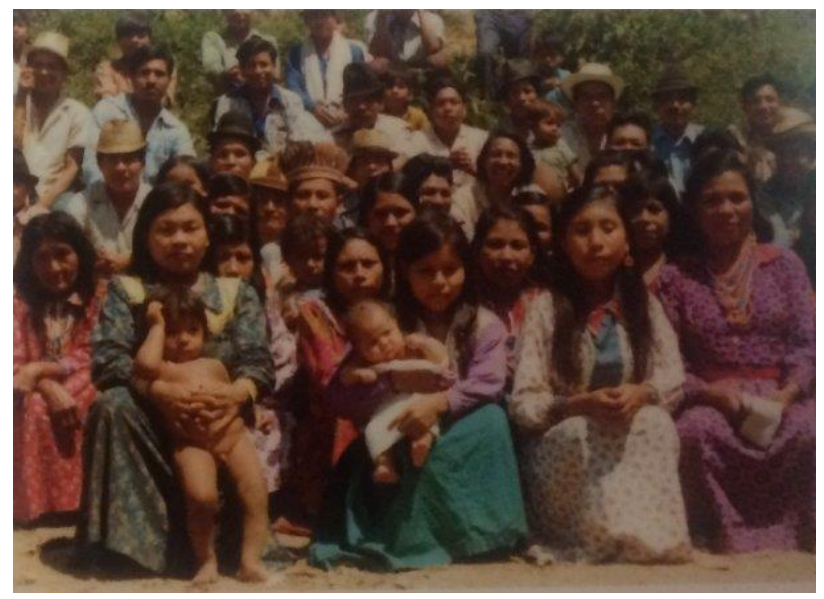

Figura 49.

Grupo embera de la vereda Humacas en el río San Juan, reunido con el Cacique de su cabildo.

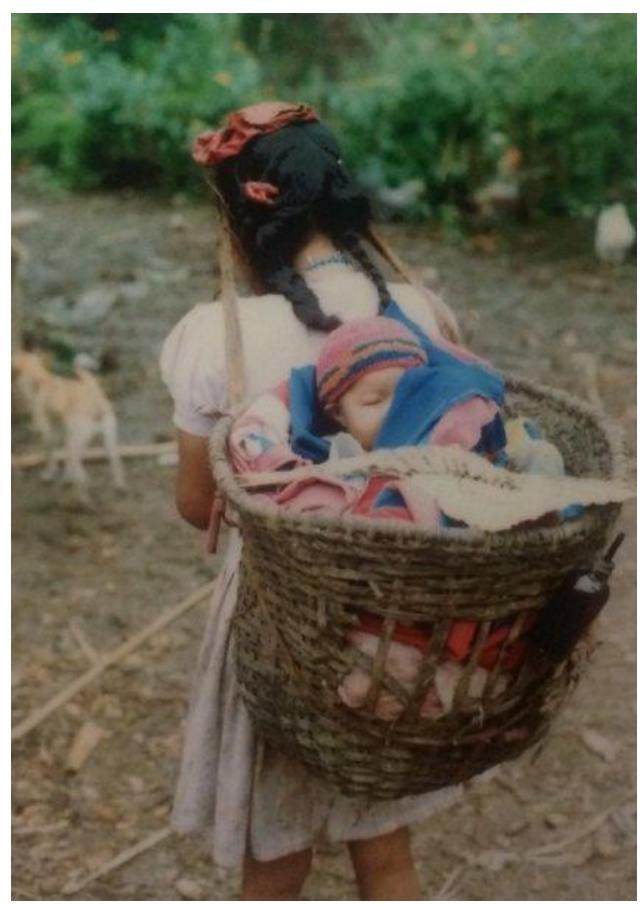

Figura 50.

Mujer llevando su bebé en un canasto usado para transportar los productos agrícolas desde la sementera a la casa.

Durante los rituales, los embera tocan música de flautas, tambores y fotutos. Tienen una cestería rica en formas, decoraciones y técnicas. Fabrican canastos para transportar productos agrícolas, cargar semillas y almacenar objetos. Coronas de cestería y de plumas eran usadas en fiestas (figura 51). 

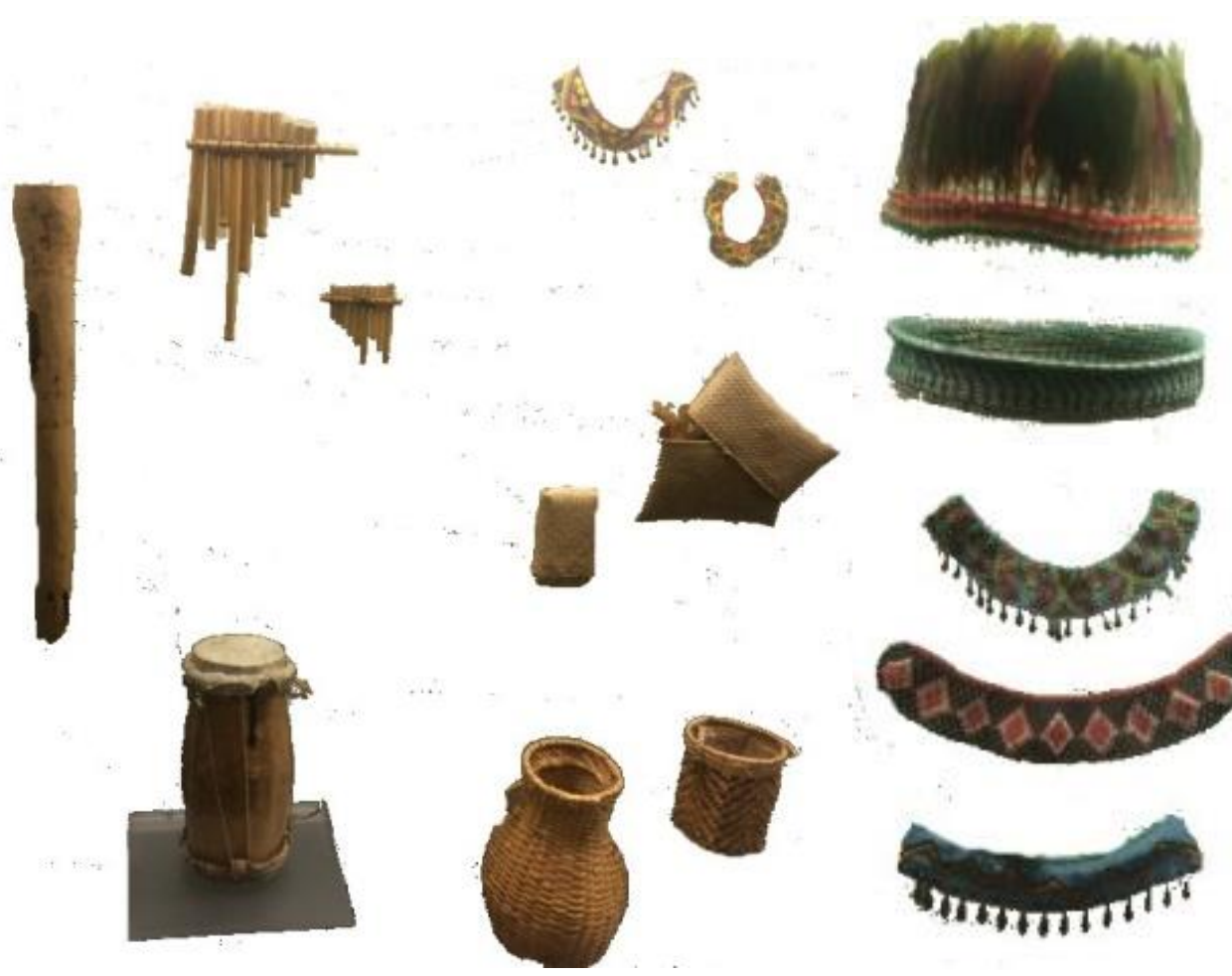

Figura 51.

Instrumentos musicales, coronas y collares embera.

Trabajan una joyería de plata martillada a partir de monedas antiguas. Las cuentas que elaboran las combinan en collares con cuentas de vidrio o chaquiras.

La parafernalia ceremonial del jaibaná incluye bastones y figuras de balso. La chicha de maíz es la bebida sagrada que provee a los embera, hombres del maíz, la esencia del ser embera. Para fermentar la chicha se utilizan recipientes de cerámica cuya forma representa los ancestros. 


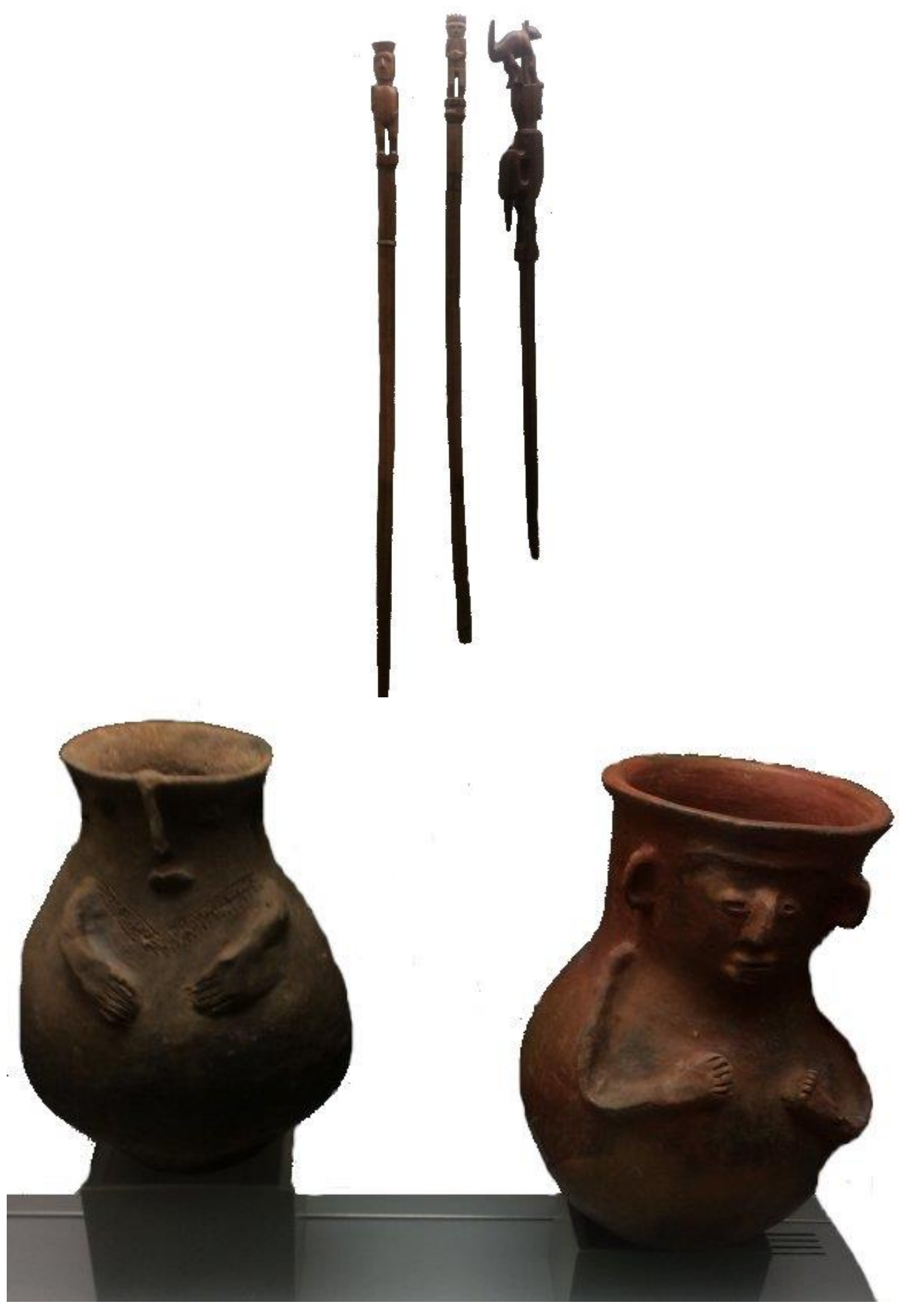

La cacería se practica con bodoquera o cerbatana, y dardos impregnados con el veneno de la rana kokoi. Esta actividad ha decaído debido a la disminución de la fauna. Gerardo Reichel-Dolmatoff, antropólogo y arqueólogo (1912-1994) afirmaba:

"Lo que los indios colombianos nos pueden enseñar no son grandes obras de arte arquitectónico, escultural o poético, sino sus sistemas filosóficos, conceptos que tratan de la 
relación entre el hombre y la naturaleza, conceptos sobre la necesidad de la convivencia sosegada, la conducta discreta, la opción por el equilibrio".

Reichel-Dolmatoff fue un estudioso incansable de las sociedades indígenas colombianas de hoy y del pasado. Sus investigaciones demostraron la diversidad, sabiduría y antigüedad de las formas de vida y pensamiento de estas culturas.

\section{Figura 52.}

Reichel-Dolmatoff realizando excavaciones arqueológicas en la costa chocoana en 1963.

El Museo del Oro Quimbaya del Banco de la República en Armenia es un aporte al desarrollo de una región que por su belleza natural y por la amabilidad e industria de sus gentes se ha convertido en un polo de atractivo turístico tanto nacional como internacional. 